Portland State University

PDXScholar

Spring 12-31-2011

\title{
Through the Eyes of Greek Cypriots and Turkish Cypriots: The Perception of Cyprus
}

\author{
Mary N. Olin \\ Portland State University
}

Follow this and additional works at: https://pdxscholar.library.pdx.edu/open_access_etds

Part of the Inequality and Stratification Commons, International and Area Studies Commons, Peace and Conflict Studies Commons, and the Race and Ethnicity Commons Let us know how access to this document benefits you.

\section{Recommended Citation}

Olin, Mary N., "Through the Eyes of Greek Cypriots and Turkish Cypriots: The Perception of Cyprus" (2011). Dissertations and Theses. Paper 871.

https://doi.org/10.15760/etd.871

This Thesis is brought to you for free and open access. It has been accepted for inclusion in Dissertations and Theses by an authorized administrator of PDXScholar. Please contact us if we can make this document more accessible: pdxscholar@pdx.edu. 
Through the Eyes of Greek Cypriots and Turkish Cypriots:

The Perception of Cyprus

\author{
by \\ Mary N. Olin
}

\begin{abstract}
A thesis submitted in partial fulfillment of the requirements for the degree of
\end{abstract}

\author{
Master of Science \\ in \\ Conflict Resolution
}

\author{
Thesis Committee: \\ Harry Anastasiou, Chair \\ Robert Gould \\ Tom Hastings
}

Portland State University

(C)2012 


\begin{abstract}
It is important to consider the effects of past conflicts on the current perceptions of the people of Cyprus and of the future generations. This thesis contends that the ongoing division of Cyprus along with the many unresolved issues regarding past conflicts have had a profound effect on how the people of Cyprus perceive new information in regard to their future.

The inquiry will explore the historical background of Cyprus and the affects of nationalism. The need for enemies, large group identity, divided societies and the need for dialogue will also be examined in relation to perception and new information.

In light of the interviews and the lived experiences in Cyprus questions arise in regard to how the Cypriots will move forward to a solution that is agreeable to both Greek Cypriots and Turkish Cypriots. With each person's perception being influenced by the past conflicts, pain and suffering how will they move forward? How has protracted conflict and nationalism influenced the Turkish Cypriot and Greek Cypriot perceptions to new information including a possible solution in Cyprus?
\end{abstract}




\section{Dedication}

To my four wonderful and amazing children: Amanda, Abraham, Andrew and Alan.

Thank you for always believing in me and giving me the strength to never give up on my dreams.

To the people of Cyprus, those who have already touched my life and inspired me, and to those that I have not met, may your beautiful island find a solution soon. 


\section{Acknowledgements}

I want to thank my friend and editor Tia for all of her hard work. A big thank you to Jon for making all of this possible and enduring the many heartbreaking set backs throughout the process. And finally a special thank you, to Alan and Amanda who helped all of this come together at the end, you were a lifesaver. 


\section{Table of Contents}

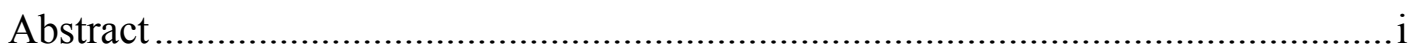

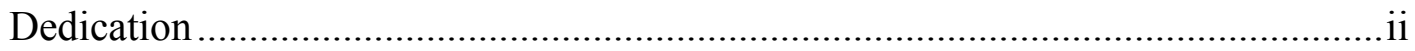

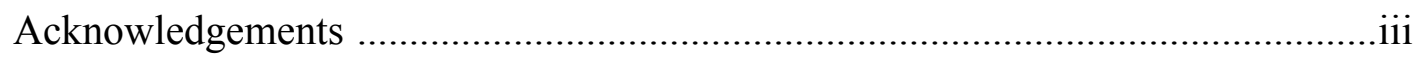

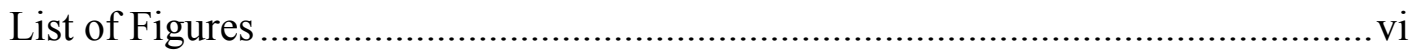

Glossary and Abbreviations ............................................................................ vii

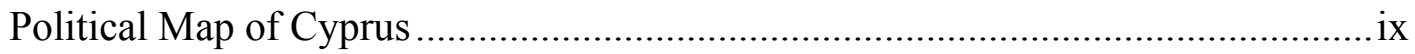

Preface

Chapter One

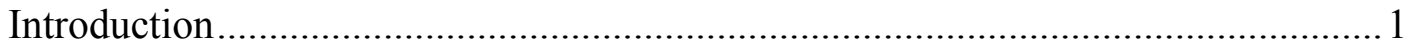

Chapter Two

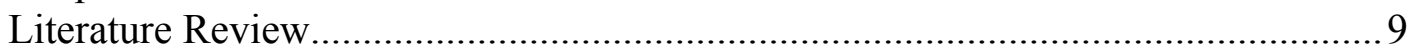

Historical Background

Nationalism

The Need for Enemies

Large Group Identity

Perceptions in Divided Societies

Dialogue

Chapter Three

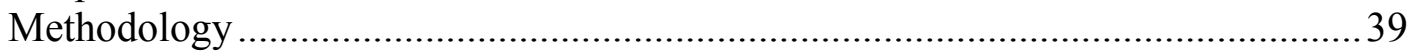

Chapter Four

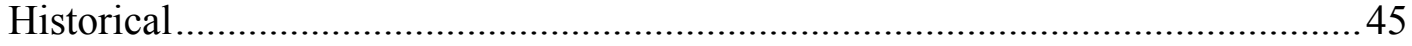

Chapter Five

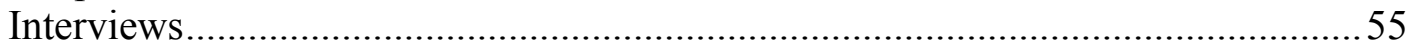

Chapter Six

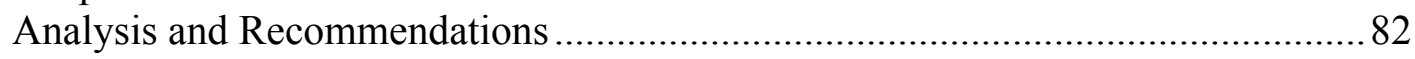

Chapter Seven

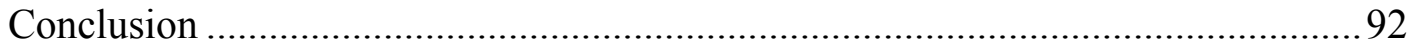




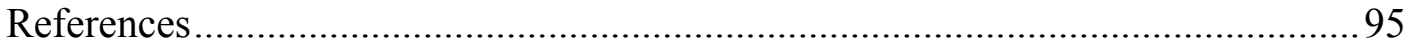

Appendix

Survey Instrument Interview Questions....................................................... 98 


\section{List of Figures}

Figure 5.1

The opening of the Crossing Points............................... 70

Figure 5.2

The opening of the Crossing Points................................p.70

Figure 5.3

The opening of the Crossing Points............................... 71

Figure 5.4

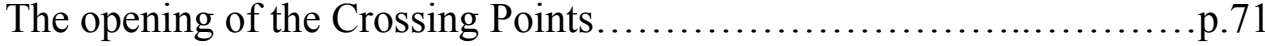


Glossary and Abbreviations

Annan Plan Refers to Kofi Annan's plan written for Cyprus

Buffer Zone Refers to the UN patrolled Green Line dividing the north and south

Coup D'etat Refers to a sudden violent or illegal seizure of government

Cypriots Refers to both the Greek Cypriots and Turkish Cypriots

Enosis Refers to union of Cyprus with Greece

EU European Union

GC Greek Cypriot

Green Line Refers to the United Nations Buffer Zone in Cyprus

Hodja Refers to the name given to the person who says the call to prayer at the mosques

Junta Refers to a military or political group that rules a country after taking power by force

Motherlands Refers to both Greece and Turkey

NGO Non governmental organization

PRIO Peace Research Institute Oslo

Taksim Refers to partition of the island

The Cyprus Problem Refers to the division of the island and a search for a solution

The Cyprus Solution Refers to the solution that both the Greek and Turkish Cypriots can agree on

The Green Line Refers to the UN patrolled demilitarized zone dividing north and south Cyprus

TC Turkish Cypriot

TRNC Turkish Republic of Northern Cyprus 
UK United Kingdom

UN United Nations

U.S. United States of America

Y.E.P Refers to the Youth Encounter Project 


\section{Political Map of Cyprus}

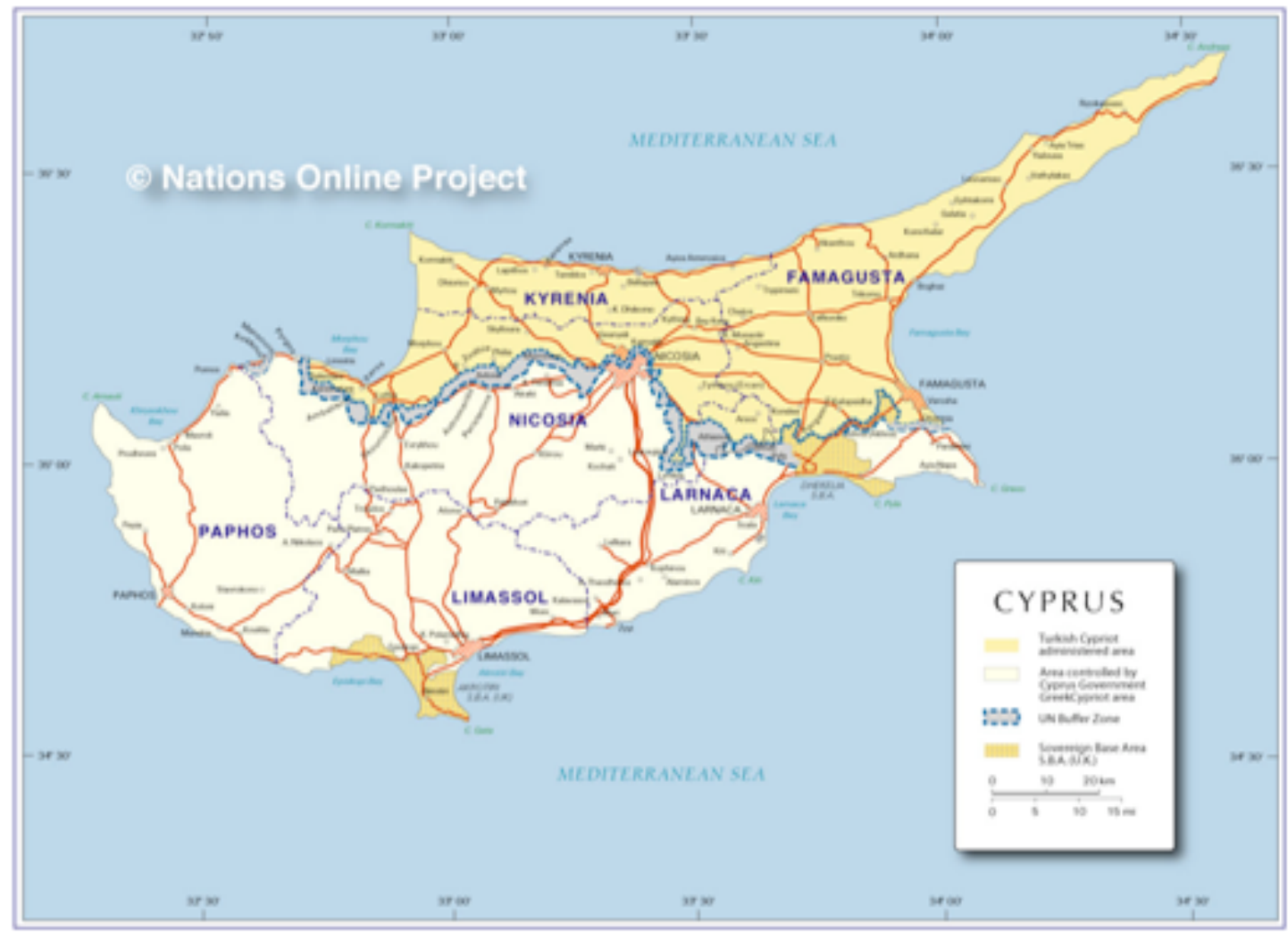

Retrieved from (http://www.nationsonline.org/oneworld/map/cyprus_map) 


\section{Preface}

Paradoxically, at the root of many group conflicts are bloodlines that establish a kind of border in times of crisis that cannot be crossed. Two groups who have been neighbors for generations may suddenly be transformed into merciless enemies, and the unthinkable may become a gruesome reality. Individual values can give way to a collective will and the monstrous vision of a charismatic leader. It is difficult for us to assimilate the horror of such acts or understand the wounds suffered by both victims and survivors. Sometimes, we can only ask, 'How could this happen?'

\section{Vamik Volkan}

Blood Lines; From Ethnic Pride to Ethnic Terrorism 


\section{Chapter One: Introduction}

"We are all exposed to different information, and we all process it in a multitude of ways because of our previous experiences and belief systems"

Benjamin Broome

The island of love, the birthplace of Aphrodite, warm beaches and charming villages.... This is a description of Cyprus, a popular vacation destination located in the Mediterranean off the coast of Turkey. Some consider it to be the crossroads between East and West. It is a country filled with wonderful foods, warm friendly people, beautiful mountains and a great deal of culture and history. However, when taking a stroll through Nicosia, Cyprus' capitol it is evident from the barbed wire, buildings with bullet holes, streets ending at cement walls with guard towers, vacant buildings with rotting sand bags still piled inside, that the past was not always so beautiful, or peaceful.

The more recent climate could be best described as 'negative peace', as Johan Gultung describes as "the absence of violence". The most recent of violent outbreaks was in 1974. For 29 years neither the Greek Cypriots nor Turkish Cypriots were allowed to pass through the United Nation (UN) patrolled 'Green Line'. In April 2003, the restrictions were partially lifted. Still, until today, the island remains divided, and the Greek Cypriots and Turkish Cypriots must show documentation to pass to the other side of their own country. During their 29 years of separation all information about the 'other side' was given to them through the media and their leaders, almost never through personal experience. The Greek Cypriots and Turkish Cypriots have lived in close geographical proximity, but in total isolation from each other, not only physically, but also emotionally. 
When the restriction was lifted, both the Greek Cypriots and Turkish Cypriots stood in long queues waiting to cross to see the other side once again after their many long, years of separation. They wanted to see their homes that they were forced to leave, and see their old friends in their former villages. During the first weeks, thousands of Cypriots crossed and many moving stories were in the media about those encounters on both sides. For many, those first crossings brought great joy and great sorrow, both for what they found after all of the years of separation and what was never to be found again. Many were hopeful that freedom of movement would be the catalyst necessary to move the peace process forward.

In 2012, the work still continues toward a Cyprus solution. The Greek Cypriots and Turkish Cypriots are not in agreement on how that solution should look. Some want to have two separate states on the island; others hope for a bi-zonal, bi-communal, bifederal state. Some believe that no solution is the solution; just leave Cyprus as it is. The Annan Plan (2004) suggested more of a loose confederation with two component states, based on the Swiss model. What state and government structure may someday become a reality remains unknown.

The Annan Plan (2004) was named after United Nations Secretary-General Kofi Annan. He was largely responsible for the creation and drafting of the document with the help of others. According to information given by the Greek Cypriots and Turkish Cypriots, they too had an influence on the drafting of the Annan Plan. The original plan went through several revisions before the final version was presented to the Greek Cypriots and Turkish Cypriots: Kofi Annan (2004) comments on the plan: 
This plan is inevitably a compromise. It does not satisfy everyone's demands. But I believe it meets the core interests, and addresses the key concerns, of people on both sides. Let us be clear. The choice is not between this settlement plan and some other magical, mythical solution. In reality, the choice is between this settlement and no settlement. Taken from, official UN website of the secretary-General's comprehensive peace plan for Cyprus- the Annan Plan. (2004). Information about the Annan Plan, remarks by the secretary-General upon presenting his final plan 03/31/04. Retrieved from http://www.hri.org/docs/annan/Statement_by_Secretary_General_March_ 31.pdf

Kofi Annan was very clear about this plan not solving all the problems and just as clear that this was the only settlement available to Cyprus.

What is known is that Cyprus was an exception to enter the European Union (EU) as a divided country. The hope that Cyprus would be reunited prior to becoming a EU member did not transpire. As a EU member, Cyprus as a whole, but the Greek Cypriot side in particular has received many of the benefits. Until recently, according to the Turkish Cypriots, the money promised to them for economic development has not been forthcoming. To this day Turkish Cypriots claim that they are not getting the financial assistance promised to them from the EU. Travel and trade restrictions continue to not be resolved either. On both sides of Cyprus feelings run high that without economic development the goal of a reunified country remains out of reach.

Given the past years of separation, the untold loss of life and more recently the new opportunities, which have been presented, how do the Turkish Cypriots and Greek Cypriots see their future? How are their perceptions affected by the past? For the purpose of this paper this will be the definition of perception referred to:

The process by which people translate sensory impressions into a coherent and unified view of the world around them. Though necessarily based on 
incomplete and unverified (or unreliable) information, perception is equated with reality for most practical purposes and guides human behavior in general. Perception. (n. d.). Business Dictionary online. Retrieved from http://www.businessdictionary.com/definition/perception.htm.

What previous negative or positive events in Cyprus have impacted the perceptions of the Greek Cypriots and Turkish Cypriots?

To that end, this paper will examine how the historical past of Cyprus continues to negatively impact the perception of all Cypriots in regard to their view of the future. The question being asked is: How are the perceptions of each community affected, which have been shaped by the conflict? How does years of protracted conflict impact the perceptions of the Greek Cypriots and Turkish Cypriots in regard to three recent events: The opening of the checkpoints, the referendum/the Annan Plan and European Union membership?

Chapter two is the literature review with highlights of Cyprus' history and how differently each side presents it. Not only do the historic viewpoints vary widely, each side emphasizes certain parts and leaves out other parts, which reinforces their nationalistic tendencies. The negative influence of nationalism continues to be the catalyst for the ongoing conflict.

The ethnic and political situation in Cyprus provides a unique opportunity to explore human tendencies in relation to conflict and large group identity. Polarized groups have many commonalities, including the need for enemies, and the need to see others as capable of atrocities that they, themselves, would never commit. Reinforcement of large group identities requires a sense of we-ness and a propensity to look for others 
who are like us, while demonizing the other. The more bonded the group becomes, either through loss, conquest, or conflict, the more likely there will be an 'us' and a 'them'.

Divided societies are groups of people who live next to each other, but have barriers dividing them. Those barriers can be religious, physical, cultural or emotional. In the case of Cyprus it has been all of the above. This multi-layered division creates a situation ripe for the propaganda to take hold and feed the people with non-truths.

Human perception, the ability for each individual to see things as only they can see it, is largely based on cultural heritage combined with previous experiences. How the past conflict and trauma in Cyprus effected the perceptions of the Greek Cypriots and Turkish Cypriots was given consideration during the analysis.

Dialogue, is one of the most important tools in conflict management or day-to-day life, there is more involved in dialogue than just talking. A common phrase is 'listen to learn', and that is one of the keys to open and productive dialogue. There are important steps to listening. This requires the control of ones own natural impulse to refute another's perceptions and resist the tendency to focus solely on your side of a disagreement.

Utilizing a qualitative methodology chapter three explores the whys of the Cyprus situation. Examining how the culture and historical experiences interact with the perceptions of the Greek Cypriots and Turkish Cypriots in their decisions is essential to forging a peaceful future. The researcher's multiple long-term visits to Cyprus from 2006 through 2010 help provide a modern-day perspective of the ongoing division. Details of the interview arrangements, structure and process provide insights into the parameters of 
the research discussed. Also, explored are the benefits and challenges of using a qualitative approach. The researcher chose to live and interact with the research subjects, which provides a unique perspective.

Chapter four explores the history of Cyprus. The manipulation by historical powers has strongly influenced the development of the fierce nationalism that impedes progress toward peace on this unique island. No research on this topic would be complete without a basic understanding of the culture and present-day issues that perpetuate the ongoing conflict. This includes historical accounts from Greek Cypriots, Turkish Cypriots, and non-Cypriots. It can be a challenge to find historical information that does not favor either the Greek Cypriots or Turkish Cypriots, again supporting the hypothesis of history and events effectively molding a person's perspective.

The research indicates that Cyprus' history is largely responsible for why the people of Cyprus have not moved forward to a reunited island. That theme will be brought forward throughout this research. It is also imperative to acknowledge the very strong connection between the people of Cyprus and their land, which for them is "home". For an American researcher to fully grasp the magnitude of such a strong connection was a challenge, when coming from a country (America) which is thought of as a more mobile society.

Chapter five includes information about the interviewees and their responses to the interview questions. This chapter explains the methods by which the interviewees were selected and what they were asked. The questionnaire consisted of three main topics, under which were the questions to collect information. The three main topics are: 
opening of the checkpoints, referendum \& the Annan Plan, and EU Membership. The information attained through the responses given to those questions was then placed into the following five categories for further analysis. The five categories are: dispelling myths, opportunity, discouragement/sense of hopelessness, inequality, and perception.

Chapter six gives an analysis of how perception affects the situation in Cyprus. The question posed is: How much does perception effect all new information given to the Greek Cypriots and Turkish Cypriots? How does the past conflict habituated history affect the perception of each Greek Cypriot and Turkish Cypriot? This chapter also takes a brief look at the historical background of the Cypriots as it relates to their decisions and actions. To that point, when entering a post conflict-zone, what is the most effective way for the people trained in conflict resolution to help people? Is it possible for a person who has just been through a conflict to receive or process the conflict resolution skills that are being taught to them?

It is a dilemma. The people, post conflict, need the information and training, but they have spent years learning to see things in a certain way. Many times that way of seeing may not allow for other viewpoints without being considered a traitor, or not being loyal to the state and its people. With such high stakes, how can change begin in a collective society without the high price of exile? In addition, objective research must not only give consideration to the past historical events, but also the linguistics and neurological predispositions of each individual. For the purposes of this paper the research will focus primarily on the effect of the historical background, its effects on perception and the barriers it creates to conflict resolution in this unique area of the world. 
This paper examines how the past experiences with mutual histories of conflict, pain, and suffering affect the perceptions of all Greek Cypriots and Turkish Cypriots in Cyprus and how that history affects the possibilities for peace in Cyprus 


\section{Chapter Two \\ Literature Review \\ "If you want to understand today, you have to search yesterday" \\ Pearl Buck}

\section{Historical Background}

This thesis explores the question of how the Greek Cypriots and Turkish Cypriots perceive several major events that have occurred during the last seven years in Cyprus.

Furthermore, what effect does the Greek Cypriot and Turkish Cypriot perception have on the eventuality of a Cyprus solution? Does that perception hinder the forward movement toward a solution? A limited amount of relevant historical data and several possible theories assist in the analysis of that question. An inquiry of nationalism; the need for enemies; large group identity; perceptions in divided societies; and dialogue will be used to examine these questions.

As researchers the goal is to listen, observe, investigate and spend time living and interacting in the community. Those things are done to achieve a better understanding of the situation and of the people that are to be studied. During that process, what became more evident in Cyprus was the influence that past conflicts had on the perceptions of the Greek Cypriots and Turkish Cypriots. How in fact, two people could experience the same event and yet still have a radically different story about it. This was a very intriguing phenomenon to witness and explore while the researcher lived in Cyprus. That phenomenon holds true in almost every aspect of life in Cyprus, from the island's history, 
to a possible solution, to the Cyprus problem. The perceptions of the Cypriots can be diametrically opposed depending on whom you speak with and what their previous experiences has been as a Greek Cypriot or Turkish Cypriot.

While living in Cyprus, it became evident to the researcher that each person's perception was based on what he or she already knew. Of course all human perception is based on previous knowledge, but in Cyprus that knowledge is radically different on each side of the island. Lederach (1996) suggests how people make sense out of different events, as well as how they are interpreted, are based on what that person already knows, or has experienced. Lederach (1996) explains that people act on what has meaning for them. That meaning is the result of accumulated knowledge. The past negative relationships in Cyprus, and at times, hostile relationships with one another, continue to define the Cypriots as individuals, and narrow how they view their future. How they perceive all information given to them has been, and is, filtered primarily through the devastating experiences of past conflict in Cyprus.

The argument that is being put forth here is that because of lived experiences both personally and historically the Greek Cypriots and Turkish Cypriots have developed a very unique perception. The two main influences on their perception that will be analyzed are; the effects of Cyprus being ruled by other countries and leaders throughout much of their history, and in addition the impact of conflict in regard to how Greek Cypriots and Turkish Cypriots view the future.

The history of Cyprus can be a challenge for even the most elite academics to decipher. Lord Hannay of Chiswick (2005) was a British Diplomat for 36 years and then 
he became the British Special Representative to Cyprus for seven years. He contends that not only do the Greek Cypriots and Turkish Cypriots have perceptions that have been impacted by conflict, but also the perceptions of the outsiders (non-Cypriots) have been greatly influenced by what they have read or heard about Cyprus. Hannay (2005) before he arrived in Cyprus he noted the historical background was very convoluted. "There is astonishingly little published material about Cyprus that is not distorted by the views of the author, who tends to be on one side or the other of a deeply contentious and embittered argument" (p. 51). Throughout the research for this paper that distortion was again and again made evident. The following brief history of the countries and various rulers who dominated Cyprus is essential to the understanding of the Cyprus conflict. This will help illustrate the unique perception of the Greek Cypriots and Turkish Cypriots, in particular how they view others, and their feelings of outsiders imposing their will upon them.

The U.S. Department of State (2007) lists the Cypriot culture as one of the oldest in the Mediterranean. As early as $370 \mathrm{BC}$, the island was inhabited and considered to be the crossroads between the east and west. The island had many rulers throughout its history: Assyrian, Egyptian, Persian, Greek and Roman. The Byzantines ruled Cyprus for 800 years beginning in 364 AD. King Richard I of England, ruled briefly during the crusades, followed by Frankish control in the late 12th Century. It was ruled by the Venetians 1489-1571, after which the Ottoman Turks took over. Attalides (2003) recounts the sixteenth century, "When the Ottoman Turks invaded Cyprus in the sixteenth century they destroyed the Venetian feudal structure which ruled the mass of 
the Greek-speaking, Orthodox Christian population in Cyprus" (p. 1). During that time the Ottomans applied the millet system to Cyprus, which allowed the religious leadership to govern their own non-Muslim minorities. This system reinforced the position of the Orthodox Church and the cohesion of the ethnic Greek population. In 1878, when Great Britain took control of Cyprus, most of the Turks who had settled during the three centuries of Ottoman rule remained on the island. In 1914, it was formally annexed by the United Kingdom at the outbreak of World War I, and in 1925 became a British Crown Colony.

During the 1950s struggle for independence from Britain, both the Turkish Cypriots and Greek Cypriots had a different vision of what the future should hold for Cyprus. The main objective of the Turkish Cypriots was taksim (partition), which would compel Cyprus to become two separate states. The Greek Cypriots sought enosis (union), which would cause Cyprus to become a Greek island. These divergent visions of the future created rising tensions in Cyprus. In 1959, Britain, Greece, Turkey and Cyprus signed the London-Zurich Agreements. The London-Zurich agreement was to be the assumed Cypriot constitution. Some of the main points were as follows; no enosis or taksim, a Greek Cypriot president and a Turkish Cypriot vice president, guidelines in regard to military forces, also Greece, Turkey and Britain would be the guarantors. In 1960, Cyprus gained its independence, and still to this day Britain retains sovereignty over two military bases.

Maria Hadjipavlou holds a Ph.D. in Comparative Social and Political Change and has extensive training and experience in conflict resolution. She has taught at various 
Universities in the United States and was a post-doctoral fellow at Harvard University.

She is Greek Cypriot and is currently residing in Cyprus. Maria Hadjipavlou (1993) gives her view of the 1960 settlement:

The 1960 settlement was basically imposed on the Cypriots by the three outside interested powers, without regard for local realities and socialpsychological needs and concerns. For example, following the struggle of the 1950s, there was much pain, misperception, stereotyping, distancing, and frustration among the different local groups that should have been addressed during the third party high-level negotiations (p. 343).

Many Cypriots still have the perception that outsiders want to impose their own will once again on Cyprus. With other rulers dominating the island throughout much of their history, it is understandable that both Greek Cypriots and Turkish Cypriots could perceive it in that way. The sense of outsiders having influence and power over Cyprus was expressed during the interviews, as was their deep desire to be in control of their own Country.

Harry Anastasiou Ph.D. is a professor of International Peace and Conflict Studies at Portland State University. He has published numerous journal articles and several books on Peace building, interethnic conflict, conflict transformation in Cyprus, the European Union and nationalism. He is a Greek Cypriot who since 2002 lives in the United States. Anastasiou (2008a) gives insight to the effects of nationalism on perception:

The inception of the republic found Cypriot society deeply divided psychologically, politically, and ethnically. The seeds of the newly established republic had fallen on infertile soil. Greek and Turkish nationalism had decisively alienated the GCs from the TCs, pitting one against the other in perpetual ethnic suspicion and rivalry (p. 94).

December 1963, inter-ethnic tensions boiled over into violence and the Turkish Cypriots 
withdrew from the government and entered enclaves.

Dr.Vamik Volkan is a Turkish Cypriot, he was a faculty member at University of Virginia Medical School until his retirement, then became an Emeritus Professor of Psychiatry in 2002. Volkan has published numerous books and journal articles. Volkan (1997) gives his perception of the conditions under which the Turkish Cypriots lived for over five years. "Between 1963-1968, Cypriot Turks were forced by Cypriot Greeks to live in enclaves under subhuman conditions and eventually occupied only 3 percent of the island, instead of the 35 percent they had previously owned. They became caged prisoners, surrounded by enemies" (p. 95).

In 1964 the UN peacekeepers arrived in Cyprus and have never left, now it is referred to as one of the longest peacekeeping missions in history. December 2009, the UN peacekeepers presence was re-evaluated and the decision was made to leave them in place. The 'Green Line' continues to be patrolled by the UN peacekeepers. The Green Line refers to the UN buffer zone established in 1964 that divides the island and runs through Nicosia, the capital of Cyprus.

In 1968, the political climate had changed and the Turkish Cypriots were able to leave the enclaves, though many had nowhere to go. The situation remained tense, though they could move about freely, many Turkish Cypriots expressed concerns for their safety. Part of the tension stemmed from the continued desire of the Greek Cypriots for union with mainland Greece and the fact that the Greek Cypriots were the majority on the island. As time went on the situation began to escalate and by 1974 tensions boiled over. 
Anastasiou (2008a) asserts a certain viewpoint by some Greek Cypriots:

The assumption that the ethnic majority of the Island had an inalienable claim to the total possession of the Cypriot state compelled the Greek an GC extreme nationalists to claim the right to denounce the constitution and independence of Cyprus and proceed to unite Cyprus to Greece a feat they attempted by use of force in 1974. In their minds, the presumed right to possess the state naturally extended to the right to take control of the state and do with it as they pleased (p. 59).

Anastastiou (2008a) explains that the Greek Cypriot nationalists and Greek Cypriots who were leading the coup which was against the republic believed that, “...the rightness of their attempted action supersede the negotiated and signed interethnic agreements that founded the republic" (p. 59).

Anastasiou (2008 a) indicates, that the 1974 Greek led coup d'etat in Nicosia, subsequently lead to the Turkish military intervention. Greek Cypriots and Turkish Cypriots were forced to leave their homes, businesses, and friends to relocate to either the North or the South, respectively. Volcan (1997) offers his perspective, "In 1974, the mainland Turkish army landed on the island to protect the Cypriot Turkish population, which was facing new threats of annihilation. This action resulted in the defacto partitioning of the island into a Turkish section in the north and a Greek section in the south and living in enclaves ended for good" (p. 97).

Broome (2005) suggests that even though many years have passed, the Turkish Cypriots have not forgotten the feeling of being treated as second-class citizens, or the fear for their own safety whenever they traveled outside the protected area during 19631974. Nor have the Greek Cypriots been able to easily forget the loss of their homes and businesses that they were forced to leave behind in 1974. How the Greek Cypriots and 
Turkish Cypriots perceived all future information given to them, was from then on, filtered primarily through the devastating experiences of conflict.

That conflict effectively divided Cyprus into two separate ethnically distinct regions. That separation did not allow for any physical contact between the two regions. The Cypriots were left with only grievous memories of conflicts past and creations of the terrible monster on the other side of the 'Green Line'.

\section{Nationalism}

"In the final analysis, it maybe the case that the spirit of nationalism and the spirit of peace are fundamentally incompatible"

Harry Anastasiou

The definition of nationalism is somewhat opaque. Nationalism can be seen as a political doctrine, a cultural ideal, or a moral ideal. It can be civic nationalism or ethnic nationalism. Regardless of how it is classified, or what name it is given, the power it wields is prodigious. Americans have not had first-hand experience with ethnic nationalism in their own country, contrary to most of the world. Anastasiou (2008 a) suggests that the history of nationalism in Cyprus has had a deeply adverse effect on the perceptions of both Greek Cypriots and Turkish Cypriots. Anastasiou (2008 a) asserts,

"The phenomenon of ethnocentric nationalism has been at the heart of the turbulent historical odyssey of the Cypriot people Greeks and Turks alike" (p. 6).

For the purpose of this paper when referring to nationalism Alter's (1994) and Anastasiou (2008 a) definitions of nationalism will be used unless otherwise noted. The hallmark attributes of nationalism embody these characteristics: 
Consciousness of the uniqueness or peculiarity of a group of people, particularly with respect to their ethnic, linguistic or religious homogeneity; emphasizing of shared socio-cultural attitudes and historical memories; a sense of common mission; disrespect for and animosity towards other peoples (racism, xenophobia, anti-Semitism) (p. 3).

Nationalism is not merely a political ideology like communism or liberalism. Rather, it is a world- and life view deeply rooted in historical, sociological, and existential conditions, both as an antecedent and consequent. As such, nationalism is a way of being in the world. It implies that nationalists have a certain view of life, society, and history, along with a code of expected behavior, and a particular understanding of identity and belonging (p. 17).

Nationalism gathers people together who see themselves as being the same, with the same objectives and encourages the dehumanization of people who are not like them. The dehumanization allows for atrocious acts of violence to be carried out for the love of nation.

The nationalist mind sees the world through a very unique perspective. One of the conditions of nationalism is the justification to use of violence. Anastasiou (2008 a) asserted that, "Simply stated, nationalism carries an inner affinity with violent conflict - a crucial, though generally unstated, historical fact” (p. 23). In part the justification of violence stems from the absolute and complete loyalty to the nation. Anastasiou (2008a) continues to assert, "More accurately, the most fundamental characteristic of nationalism lies in its overt or covert absolutization of the idea of the nation, while conceptualizing the national community as an ethnically homogeneous identity group” (p. 19).

Ignatieff is Canadian, has a PhD in history from Harvard University, and has published many books and articles. Ignatieff (1993) offers this perspective on nationalism, "It is not one thing in many disguises but many things in many disguises; 
nationalist principles can have dreadful consequences in one place, and innocuous or positive ones in another place. Context is all" (p. 14). When the Greek Cypriots or Turkish Cypriots in Cyprus reference their historical past, it is very common for one ethnic groups celebration of victory to be the other ethnic groups tragic loss. Nationalism gathers people for the cause, and justifies their actions as being for the good of the people and the nation. It exalts leaders and creates a unique bond between people to do whatever is necessary for the good of the group.

In Cyprus, as with many countries around the world, nationalism had an immeasurable influence on why and how many things were done throughout the years. Anastasiou (2008 a) suggests the following, "It is true that nationalism rose to historical preeminence and influence because it spoke to certain human needs" (p. 41). In part because nationalism does serve a purpose, though perpetually leading to suffering for one of the groups.

In Cyprus, the old nationalistic rhetoric lingers, and waits to rear its ugly head from time to time. Events such as the opening of the checkpoints, the Annan Plan and EU membership created a perfect climate for nationalism to be reignited. Before the vote on the Annan Plan the Greek Cypriot media used the tragic history of the past conflicts with the Turkish Cypriots and emphasized how little the Greek Cypriots would be getting back if they voted yes to the Annan plan. The reminders of the past pain and suffering as well as the possibility of such limited return of land to the Greek Cypriots had a very negative impact on their perception of the Annan Plan. In the end the Greek Cypriots voted no to the Annan Plan. In part, this was a very effective nationalistic media tactic, 
to reawaken old historical memories.

On the Turkish side one very obvious reminder of the past is the giant Turkish flag painted to cover one side of the Pentadaktilos mountain range that faces the Greek side. This flag can be seen for approximately 20 miles on the Greek side. When Greek Cypriots observe the flag painted on that mountain, they are reminded of the past, and the pain and suffering caused by the Turkish military. In comparison, on the Greek side though there is not a giant flag painted on a mountain but there is the Greek flag, which is found flying next to the Republic of Cyprus flag. When the Turkish Cypriots see the Greek flags, it is a reminder of the past suffering while living in enclaves. For some Greek Cypriots it represents a desire to unify Cyprus with Greece. These flags serve as daily reminders of historical nationalistic tribulations of the past.

Ignatieff (1993) states the following, "Freud once argued that the smaller the real difference between two peoples, the larger it was bound to loom in their imagination. He called this effect the narcissism of minor difference. Its corollary must be that enemies need each other to remind themselves of who they really are" (p. 21,22). A Greek Cypriot is someone who is not a Turkish Cypriot and a Turkish Cypriot is not a Greek Cypriot. "Without hatred of the other, there would be no clearly defined national self to worship and adore" (p. 21, 22). Nationalistic politics have been able to use the minor differences to create a distortion of history, where one side can remain blameless victims and the other side is monsters capable of the most horrific acts. From a foreigner's perspective, the Greek Cypriots and Turkish Cypriots may appear very similar. Many of the foods are the same or similar; as well as their sense of family and community; their 
respect for elders; their love of music and dance; culturally the list of similarities is considerably long.

In fact, the topic of similarities is one of the major things addressed by the Seeds of Change youth program in regard to Cyprus. They provide opportunities for young people to learn about the 'other side'. During one of the many workshops, they separated the youth's into two groups, Greek Cypriots in one group, and Turkish Cypriots in another. While in those groups, the students named as many of their favorite foods and family traditions as they could. Then both of the groups joined together and compared their lists. When they began to discover how many foods, traditions, and music they had in common and realized how similar they are culturally. They began to see each other as just teenagers, with typical teenage problems. For many youths, this may be the first experience interacting with the 'other', and it can be very revealing. These young people are surprised at how much they are alike, and that the 'other', is not a monster at all, but a person like them with very similar problems, hopes, fears, and dreams. These sorts of group interaction among the youth are a critical part of eradicating any residual nationalist perceptions that have been handed down to the youth.

The last violent conflict in Cyprus was in 1974, and still today, 38 years later the pain, suffering and biased historical information is alive and well, even among the islands youth. Though, these youngsters were born long after the last violent hostilities had ceased, mainstream propaganda disseminated through the government, schools, families, and religious cultural leaders has been able to keep some of the nationalism alive. Education and nationalism have worked together to inform the children about their island 
and its inhabitants. Hannay (2005) states that, "Children are brought up to regard the other side as the 'enemy', taught bigoted songs at nursery school and given time off to demonstrate on significant anniversaries" (p. 232). The message of hatred and the celebration of your own groups' victories (which is usually the other groups tragedy) eventually becomes each child's reality. That is how most grow up knowing the history of Cyprus, through the distortions of nationalistic views.

During the research in Cyprus there were many a conversation with a local Cypriot shop owner and others over a cup of coffee. The conversations were with both Greek Cypriot and Turkish Cypriots. During those conversations the Cypriots shared their personal accounts of suffering and loss, or they shared the history they had learned about the violent conflicts in Cyprus. One detail that was more commonly shared was the statistics about the missing. Anastasiou (2006) sums it up very succinctly, "Nationalism collects and stores pain in peoples' collective memory. For the nationalist mind, to forget is impossible, to forgive unthinkable" (p. 150).

The inability to let go of the past is a significant deterrent to finding a solution in Cyprus. Some believe the inability to let go of the past is why the Annan Plan did not get the yes vote that it needed from the Greek Cypriots. In part, because the influence of nationalism continues to effect the decisions made by the Greek Cypriots and Turkish Cypriots in regard to the future of Cyprus. Nationalism enhances the bonds between people who see themselves as similar, but despises the 'other' for he is the enemy. 


\section{The need for enemies}

"Virtually whenever it appears, excessive enmity can be traced to pain, injury, loss, and rage"

\section{David Barash}

David Barash PhD is a professor of Psychology at Washington University. He has published over 30 books including some on human aggression and peace studies. Barash (1994) suggests that enemies can help to define people. Some examples: the Hatfields without the McCoys; Captain Ahab without Moby Dick; the United States without the Soviet Union, the one is defined by the other. "There is nothing so disorienting as the loss of a good friend, except, perhaps, the loss of a good enemy" (p. 9). The need for an enemy as definition of oneself paradigm was reinforced throughout the research process in Cyprus.

The researcher heard the term, 'monsters' and 'the enemy' used to describe the people from the 'other side'. The 'other side' is the phrase or term given to the researcher for the people living on the opposite side of the UN line. By definition if it was a Turkish Cypriot speaking then the 'other side' would be referring to the Greek Cypriots who live in the south and for the Greek Cypriots the 'other side is the north where the Turkish Cypriots live. For the Cypriots the enemy has become essential to their definition of self, because it is what they are not. Here we look at the correlation of perception as it relates to the need for enemies. More specifically how the perception of needing enemies may affect Greek Cypriots and Turkish Cypriots ability to accept change or a possible solution. 
This identity, this sense of not being like the enemy, is an integral part of the nationalism that many of the Greek Cypriots and Turkish Cypriots adhere to. Barash (1994) makes an interesting point, perhaps the question to pose, is 'who are we really', instead of 'who is your enemy'. For Cypriots the two may be inseparable, unless they are willing to get beyond their deeply held assumptions. Some questions to ask: Is that other group of people really the enemy? Has time allowed for the exaggeration and distortion of what at one time had some truth to it?

How one views themself is important to consider because of the role it plays in how they see the world. In psychology, the 'attribution error' is often used to describe misperception of others. In simple terms it is the propensity of some people to blame the actions of other people on that individuals personality rather than the situation. Although some people can justify their own personal wrongdoing as being circumstantial and not by any means caused by them. But can only see the wrongdoing done by others as a reflection of that person's innate character. Barash (1994) suggests, “...our opponent behaves nastily because he or she is, well nasty" (p. 283). This human tendency helps to create and enhance the 'enemy image'.

Nationalism requires dehumanization in order to fulfill its mission to remove the enemy. Barash (1994) asserts, "Enemies, we all know, exist somewhere out there, not inside ourselves. And moreover, their role is to be overcome, defeated, and conquered" (p. 17). The enemy is seen as prodigiously evil and more powerful than they actually are. They are so evil and powerful that future generations must be educated about their abhorrent ways. In Cyprus, the pain from past conflicts has been passed down through 
the generations so that even now the youth hear about it as though it were a recent event.

Barash (1994) gives definition to the term, passing along the pain, which is what has transpired in Cyprus for several generations:

It is remarkably widespread, so much so that it is virtually second nature, even something of an obsession. Yet, most people are so immersed in the culture of pain-passing that, like a fish that takes its surroundings so much for granted that it would never consider the water it swims in to be 'wet', we remain blissfully ignorant of its existence. The passing of pain also helps explain an important part of the enemy system, since much in the identification and creation of enemies takes place when people take part often unknowingly - in this ritual, one that has virtually the power and automaticity of a reflex (p.167).

Throughout the research some important questions began to arise. How could the situation in Cyprus ever change as long as they continue to pass the pain from generation to generation? How could they ever allow themselves to let go of the past and move toward the future? Something will have to change in order for that to happen. Barash (1994) suggests that people have to move beyond the attribution error and begin to see the 'other' as people motivated by limitations, problems, and of course aspirations that are just as legitimate as their own. This change will come when relationships can be created based on empathy instead of enmity.

\section{Large Group Identity}

"Once the basic trust of members of a group is shaken, it gets perverted and is replaced by a blind trust"

Vamik Volkan

Volkan (2004) suggests, "The concept of large-group identity describes how thousands or millions of individuals, most of whom will never meet in their life times, are 
bound by an intense sense of sameness by belonging to the same ethnic, religious, national, or ideological group" (pg. 11-12). The large group identity is not something that people typically focus on during the day under normal circumstances. Volkan (2004) argues that people do not usually feel intensely American, Swedish or Polish. The association with a large group is not something that would normally be at the forefront of a persons mind as they go about their daily activities. "Our relationship with our large group identity, in ordinary times, is like breathing. We breathe constantly, and we are unaware of it unless someone reminds us of the fact that we need air to survive" (p. 12). Most, rarely give thought to inhaling or exhaling until illness threatens the ability to breath. The same with large group identity, when the group feels threatened that is when they become aware of their large-group affiliation. Following are theories about large group identity in regard to the effects on perception in Cyprus.

Cyprus has two primary ethnic groups, the Turkish Cypriots and the Greek Cypriots. The word ethnicity comes from the Greek word ethnos, and in general refers to ethnic character, background, or affiliation. Volkan (2004) suggests that ethnicity incorporates religious and national identity. If national identity is part of a person's ethnicity that could offer some explanation as to why a person could be so loyal to their national cause. "Ethnicity, then, incorporates religion as well as language; connected with shared images of the group's history, it establishes an especially sharp sense of 'us' and 'them'" (p. 26).

In Cyprus, this strong sense of we-ness can be felt on both sides of the island. At times this sense of we-ness has become inflamed and at times people have chosen to act 
violently toward one another. Part of the research for this thesis allowed for living among, and doing everyday activities with Cypriots both in the north and the south. During the research time in Cyprus there was the occasional loud and angry outburst from one or more Cypriots about an action committed by the 'other'. There are many activities that help to contribute to the large group feeling such as chosen glories and chosen traumas.

Volkan (2004) gives definition to the terms chosen glories and chosen traumas. Volkan explains how chosen glories occur in large groups. "Large groups tend to hold on to mental representations of events that include a shared feeling of success and triumph among group members; heavily mythologized over time, such events and the persons appearing in them become elements of large-group identity" (p. 47). The chosen glories are then passed from generation to generation through parental interactions as well as through participation in ceremonies that celebrate those successes. The chosen glories are commonly used to encourage group identity in times of crisis.

Volkan (2004) explains that chosen traumas are the collective memories of past incidents that forced the large group to experience common losses, feelings of helplessness and to be victimized by the other group. The chosen traumas are carefully stored away and nurtured. They will be used in the future, to incite and inspire the group to collective action. It is suggested that the actual history of the events becomes of less importance compared to the sense of sameness it created. The chosen glories and chosen traumas help to create a sense of sameness and a distortion of history that has a farreaching effect on each persons perceptions. 
An example of the influence that chosen traumas and chosen glories can have was witnessed during the time leading up to the referendum. On the Greek side the leaders chose the media as a tool to promote hate speech and propaganda about the Annan Plan. Through the media the Greek leadership exhorted the people to remember the past, and not to forget what the Turkish Cypriots had taken from them.

Volkan (2004) gives more insight on effects of the chosen trauma, "In what I call a time collapse, the chosen trauma is then experienced as if it has happened only yesterday; feelings, perceptions, and expectations associated with the past heavily contaminate those connected to current events and current enemies, leading to irrational political decision-making and destructive behavior" (p. 50). Based on that theory the Greek Cypriot perceptions of the Annan Plan were being filtered through what they had lost. The media and leaders on the Greek side encouraged the Greek Cypriots to remember how their land had been forcibly taken away from them in 1974 and highlighted how little they would get back if the voted yes to the Annan Plan. Volkan (2004) explains that, "In times of crisis and terror, leaders can heal or poison their followers" (p. 13). As with all groups, but especially large homogeneous groups, leaders have the capacity to calm and positively direct with their words or actions. They also have the ability to magnify and exaggerate the unforeseen dangers. Unfortunately, in Cyprus leaders of both sides have frequently focused on the negative when it comes to situations that involve the other side. 


\section{Perceptions in Divided Societies}

"We don't see things as they are. We see them as we are."

Anais Nin

Many a Greek Cypriot or Turkish Cypriot will tell you about how they lived for many years peacefully together in mixed villages. Those same Cypriots believe that it was the outside forces involvement in Cyprus that caused the problems. Usually referring to both motherlands, Greece and Turkey and sometimes the United States and the United Kingdom will be thrown in the equation. Then there are some Greek Cypriots and Turkish Cypriots who grew up knowing that the Greek Cypriots and Turkish Cypriots are not like each other at all, because that is what their parents and grandparents had told them. The perceptions of the Greek Cypriots and Turkish Cypriots of Cyprus are varied. It should be kept in mind that Cyprus is a relatively small geographical location with shared history and years of separation.

Cyprus is still divided with the legal opportunity to cross now. During those years of separation the Greek Cypriots and Turkish Cypriots had the opportunity to form negative perceptions of one another. John Paul Ledrach, is a professor at Notre Dame University, gives some insight on perception. He has been involved in peace and reconciliation in several areas of the world in addition to publishing several books on conflict transformation and peace. Lederach (1997) suggests, "This immediacy arises from the close proximity of conflicting groups, the shared common histories of the conflictants, and the dynamic of severe stereotyping coupled with radically differing 
perceptions of each other". This is in part because of the closeness of the other group, frequently a neighboring village, or in the same community (p. 13). Cyprus was geographically divided from 1974 to 2003 . During that time the Cypriots were not allowed to cross the Green Line. For almost 30 years they were physically and emotionally separated, though they could see the other side.

Papadakis is Greek Cypriot; he holds a PhD. in Social Anthropology and is currently an Associate Professor at the University of Cyprus. He has published numerous journal articles on Cyprus in addition to two books. Papadakis (2005) reflects on growing up in Cyprus, "We grew up thinking that Greeks and Turks were opposites; they had nothing in common" (p. 32). That was what Papadakis remembers being told as a child in Cyprus and that is what he carried with him into adulthood.

Papadadakis (2005) describes his mindset and motives for traveling to Turkey in his book about Cyprus called, Echoes From the Dead Zone. Papadakis describes his position and motivations, “..Yiannis Papadakis, firmly planted in the Greek Cypriot world, sets out to discover "The Other' - the much maligned Turks". With some apprehension he decided, "to travel to Constantinople (to his Greek worldview it was sill Constantinople) to learn Turkish" (book cover). What he found is that it was Istanbul, and that Turkey was not what he thought it was based on his childhood knowledge. While Papadakis was in Turkey to learn Turkish, to his surprise he learned much more. He gives great insight as to how the stories of childhood become your reality until they are disproved.

Papadakis (2005) describes the church bells and the hodja's calling on the other 
side in the afternoons as follows. "A battle was being waged over who would dominate the soundscape. Churches had loudspeakers pointing to the occupied north and the mosques had them pointing towards the free south" (p. 50). As was mentioned perception is everything, note the word choice, 'occupied north' and the 'free south'. That perception is unfortunately the dominant one heard in Cyprus.

During their long period of separation, many of the people who at one time lived together in mixed villages learned to see each other differently. Both Greek Cypriots and Turkish Cypriots tell stories of playing with one another as children and although the new freedom of movement will in itself not change the situation, many feel that it is a step in the right direction. Hadjipavlou (2007) suggests, "Geographical and psychological separation as well as lack of the institutional structures to get to know each other's cultural achievements and concerns have kept the citizens of both communities ignorant of each other" (p. 70). Just bringing the people together will not dispel the myths that have been created and encouraged throughout their long separation. Hadjipavlou suggests that leadership should develop and encourage structured programs and workshops to help on a personal level. This would give the people of Cyprus some guidance in productive and peaceful ways to move into the future. Hadjipavlou suggests that the current perceptions that the Greek Cypriots have of the Turkish Cypriots and vise-versa will not change until some systems of education and training are put in place to assist with that transformation.

Some see Cypriot identity as one of the obstacles to acceptance of the other. Do Greek Cypriots and Turkish Cypriots have an identity that is separate from their 
motherlands? Muzaffer Yilmaz holds a PhD. in Conflict Analysis and Resolution from George Mason University. Yilmaz suggests that for peace to come to Cyprus the issue of having a Cypriot identity must be addressed. Yilmaz (2005) asserts that, "In Cyprus, the real problem has been, and still is, the lack of majority identifying themselves as Cypriots" (p. 2). Yilmaz's argument about identity is that there needs to be a separation from the motherlands and a separate Cypriot identity established. Yilmaz points out how the connection to the motherlands can be seen throughout the island, through the displays of flags. Typically, a mainland Greek flag can be seen next to a Cyprus flag and likewise in the north a mainland Turkish flag next to a Cyprus flag. In many ways the flags help to remind the Cypriots of the connection with the motherlands.

This connection with their motherlands and the division of the island is not only seen in displays of flags and statues, but also in another very powerful way, the media. Dr. Sezai Ozcelik is Turkish and holds a PhD. from George Mason University and has published numerous journal articles on peace and non-violence. Ozcelik (2005) asserts how the media impacts Cypriot perception:

The two communities also had their own newspapers and other publications which have mostly produced a media war between two sides. The local press in the island together with imported items from Greece and Turkey emphasizes Greek-Turkish antagonism and enhances mutual fears and stereotypical perceptions (p. 7).

There is work being done in Cyprus to try to address that very issue. The thought has been put forward that the media instead could be a tool for change and enlightenment at a conference attended by the researcher. The suggestion was made that both the Greek Cypriots and Turkish Cypriots could work together on this. Hopefully that will continue 
and attract more supporters in the future.

Ozcelik (2005) addresses the psychological barriers of identity. Despite the fact that Greek Cypriots and Turkish Cypriots have shared the same island for over 400 years and even after the Republic of Cyprus was established in 1960, the Cypriots still continued to celebrate the national holidays of the motherlands. "After the independence, the two communities continued celebrating the national holiday so Greece and Turkey which were mostly directed against each other" (p. 7). In Cyprus there have been both physical and psychological barriers, which helped to promote conflict.

Lederach (1996) suggests the following, "Conflict also transforms perceptions, of self, others, and the issue in question, usually with the consequence of less accurate understanding of the others intention and decreased ability to clearly articulate one's own intentions" (p. 18). The Cypriot perception has been based on history given to them from their respective motherlands, and from living through oppression and conflict conditions. What effect has this had on the Greek Cypriots and Turkish Cypriots ability to see things with an open mind? Does living through conditions of protracted conflict create a narrow myopic view that is filtered through anger, sadness, and grief? Is it even possible for a Cypriot to see that both the Greek Cypriots and the Turkish Cypriots must acknowledge the pain and suffering of both sides?

As someone who also lived in Cyprus, Benjamin Broome worked with both Greek Cypriots and Turkish Cypriots on various projects and was involved in many of the conflict resolution training sessions. He has analyzed the history of the conflict and the roles of both the Greek Cypriots and Turkish Cypriots in that conflict. In addition, he has 
given his perspective on why he believes there is no solution to the Cyprus problem: the 'blame game'. Broome (2005) "If there has been one consistent characteristic of the Cyprus conflict during the past forty years, it is the attempt of each side to place blame on the other for 'starting' the conflict, for instigating various provocative events, for the break down of negotiations, etc.” (p. 84).

In general there is a tendency to blame the other for ones own shortcomings. The Cypriots have years of conflict, which includes pain and suffering, and the division of their island. To achieve peace requires the letting go of the past and looking toward the future. To do this both sides must take responsibility for their own part in the pain they caused the other side. Each side must recognize the mistakes they made in order to move forward. Both Greek Cypriots and Turkish Cypriots must find a way to see the necessity of building relationships and letting go of the blame.

For many years the Cypriots lived in mixed villages, they could be found sitting at the same cafes in the evenings. One Turkish Cypriot interviewed pointed out where the Greek families lived on his street when he was a child. He told stories about how they all played together as children. A Greek Cypriot dentist told stories about playing together with Turkish friends as a child in the north before they had to move to the south. There were many stories about relationships between the Greek Cypriots and Turkish Cypriots prior to the conflicts and the separation. After the separation all that was left were the memories of relationships of days gone by. From then on until the checkpoints were opened all information was given on each side about the other side through the leadership and media. It is common knowledge that each person sees the same event very 
differently depending on the past life experiences.

If you have ever been one of several witnesses to a car accident and then had to give your eyewitness account of what you saw to a police officer, you may have been dumbfounded by the reports of others. The same accident described by different bystanders can sound entirely different because what is seen and experienced in the present is always being filtered through personal past experiences and knowledge, as well as whatever else is on your mind. Across all nations and cultures, personal filters create an astonishing difference in the eyewitness accounts of the same event. In Cyprus not only do the Greek Cypriots and Turkish Cypriots have their own past personal experiences to filter everything through, they have a history of inter-ethnic conflict and mistrust which distorts and impacts what they see and hear.

When groups of people are trying to move forward and build relationships the hope is that there is a certain amount of trust and empathy amongst the group. How then can the Cypriots have trust and empathy for one another, when their communication with the other side has been filtered through a history of protracted conflict and nationalism? Anastasiou (2007) addresses perceptions, "Throughout any history of antagonism and reciprocal pain-inducing incidents of violence, conflict-conditioned interactions between rival groups always lead to divergent perceptions of past history and present reality, and, by projections, to divergent visions of the future" (p. 64). The Cypriots shared past, filled with pain and suffering both real and imagined, has an immense influence on the possibilities for future.

When the past has been filled with violence and traumatic experiences it tends to 
move people further and further away from a balanced judgment. Anastasiou (2008) suggests, "The memory of pain, different in content and references for each community, has constituted a major parameter in the structure of the Cyprus conflict that has affected communication between the two sides" (p. 154). In Cyprus, much of the communication is primarily focused on the past injustices committed by the other side. When communication is then redirected to focus on the future, it repeatedly deviates back to the pain and suffering of the past. Part of this obsession with loss and the need to continue to dwell in the past stems from years of separation and the inability to actually see and interact with each other.

Anastasiou (2008a) explains divergent perceptions:

The respective experiences and derivative, existential patterns of meaning by which each community has interpreted the various facts, events, and behaviors-be they their own or those of the other side-have bee configured into frameworks that are not only mutually exclusive but also antithetical to each other (p. 154).

The prolonged separation fostered a historical record that has become intensely mythologized for both Greek Cypriots and Turkish Cypriots. This has served to solidify the negative perceptions that the media and leadership encourage.

During those years of separation the information given to both the Greek Cypriots and Turkish Cypriots was filtered through the nationalistic media and leadership without any direct contact to dispel any of that information. Anastasiou (2007) addresses the influence of propaganda on perception, "Once the rival parties become separated, the content of propaganda becomes the sole source of knowing the other side. Objective reality thus becomes concealed as the content of propaganda becomes the only reality" ( $p$. 
65). Over time and separation, the Cypriots created myths and stereotypes about each other.

Anastasiou (2007) suggests the following, "Direct engagement initiates a process that helps to defuse the content of propaganda and to dismantle the socio-psychological conditions under which propaganda thrives" (p. 71). Since 2003, the Greek Cypriots and Turkish Cypriots have had the opportunity to pass through the checkpoint to the other side; this was the beginning of seeing each other with their own eyes instead of through the eyes of the media and leadership. Hadjipavlou (2007) offers her perception of the crossings, "Through the 'crossings' the enemy not only acquired a face, a name and a new possibility, but also, to the surprise of both sides, they discovered the Other honored the same elements of shared Cypriot culture, hospitality and traditions" (p. 61). It was a beginning, a step in the right direction. So the question on everyone's mind is, where to go from here?

\section{Dialogue \\ "In true dialogue, both sides are willing to change" Thich Nhat Hanh}

Dialogue is an essential tool for resolving conflict. The conversation of true dialogue serves to provide insight that contributes to greater understanding on both sides. David Bohm has a PhD. in Physics. He has worked with both Robert Oppenheimer and Albert Einstein. Bohm (1996) suggests an image of "a stream of meaning flowing among and through us and between us" (p. 7). Furthermore, according to Bohm a 
discussion is similar to a ping-pong game, where ideas and thoughts are tossed back and forth, usually in hopes that your own is best. Too often in discussions the more important goal is to win or be right. In dialogue there are no winners or losers. In dialogue the goal is to learn from each other and if one wins, everyone's a winner. Essential to constructive dialogue is the ability to listen. Following is an analysis of dialogue and the effects on perception or perhaps more accurately the changes in perception.

In the phrase 'listen to learn', Broome (2005) suggests this is especially important during a disagreement. "Most of the time, in such situations we listen so that we can refute, correct, or challenge what someone has said. Or we listen so we can better prove our point” (p. 89). In Cyprus during negotiations one of the issues was the tendency to listen only to refute based on each sides past adversarial narrative. As Broome suggests if 'you listen to learn' what is heard is very different because you are in learning mode. It is suggested that when the receiver appears to be learning the speaker is validated. This sort of validation alleviates some tensions allowing for more dialogue to occur (p. 90)

Broome (2005) explains how difficult it is to share such a small geographical space with people that are not respected, liked and thought of as the enemy. The Turkish Cypriots and Greek Cypriots paint the same negative image of each other (p. 90). One point of view is that the lack of productive, meaningful dialogue has negatively impacted the perceptions of the Cypriots as to the best way to move forward. What are some of the other influences on perception?

According to Bohm (1996) "Most of our basic assumptions come from our society" (p. 12). This includes how the society works, what kind of person we should be, 
and how relationships should work. These assumptions and opinions may vary from group to group. Bohm (1996) suggests, "In almost any group you will probably find a great many different assumptions and opinions of which we are not aware of at the moment" (p. 12). In Cyprus, the Greek Cypriots and Turkish Cypriots have their own individual communities from which their assumptions and opinions have been formed.

Bohm (1996) explains the need to defend "our truths", "It is as if you, yourself are under attack when your opinion is challenged. Opinions thus tend to be experienced as 'truths', even though they may only be our own assumptions and your own background". You get them from your family, friends, teachers, or from reading about it. "Then for one reason or another you are identified with them, and you defend them" (p. 10). It feels as though you are being personally attacked because you have become intrinsically connected to those assumptions and opinions. Bohm describes it as defining who you are.

As people become intrinsically identified with their opinions, for the most part they do not even realize it. Who we are; what we believe, and what we think, all becomes part of our personal identity. Bohm (1996) points out, "At times we may be conscious that we are defending them, but mostly we are not. We just feel that something is so true that we can't avoid trying to convince this stupid person how wrong he is to disagree with us" (p. 13). As polarized thinking increases over time, our tolerance for dissent diminishes and creates a situation where whatever the other suggests is can be perceived as an attack 


\section{Chapter Three}

\section{Methodology}

A qualitative approach was used to allow for information to emerge from the Cypriots and from the questions used during the interviews. The questions used for the interviews were open ended, and in addition, observational data was gathered during the interviews. Later in this chapter more details will be given about the interviews and about the survey used. During the analysis of the interview responses, the goal was to look for emerging patterns, and to develop a theory about perception as it pertains to conflict resolution in Cyprus. While in Cyprus, the researcher had the opportunity to spend a significant amount of time observing, listening, and talking with the Greek Cypriots and Turkish Cypriots.

As a researcher one must constantly be aware of one's own bias and seek to be objective. It is, however, virtually impossible to not include one's own personal values and to be totally unbiased. Particularly when living with and interacting on a daily basis with the people. It is important to be constantly mindful of one's bias while in the process of gathering and synthesizing the data.

The researcher was in Cyprus for three months in the fall of 2006, one month in the spring of 2007, two months in the spring of 2008 and two months in the spring of 2010. The researcher lived alone in a flat on the Greek side in 2006, and then on all return visits lived with Turkish Cypriots in their homes. The researcher spent a great deal of time socializing and participating in all daily activities with both Greek Cypriots and Turkish Cypriots. Experiencing life through the eyes of the Cypriots was the focus, to 
better understand their perspective, and how they filtered the information they were given by others. The purpose was to establish an understanding of the issues in Cyprus, based on the Cypriots perspective. The daily activities that the researcher was able to be involved in were felt to be key to a better understanding of how perception can change what is heard, and how it is understood.

The first research trip included volunteering at the Cyprus Neuroscience \& Technology Institute, which is a Non-Governmental Organization (NGO) for two months in the south. The researcher's flat was about a 20-minute walk from the NGO office. The building where the rented flat was located was on what is termed a pedestrianized street; therefore, on a daily basis there were Greek Cypriot vendors and shop owners to interact with while going to and from work. The researcher was also invited to many different functions. There were conferences, meetings, and visits from Palestinian refugees, speakers whose topics ranged from human trafficking in Cyprus, to the impact of settlers from mainland Turkey. There were many dinners, lunches, and excursions to see the vast history of Cyprus. The researcher was able to meet and have conversations with dentists, teachers, lawyers, writers, doctors, and ordinary Cypriots from all walks of life in both the north and the south. All of these opportunities gave the researcher more insight into how perception influenced what the Cypriots saw and heard, and what information they chose to share and how they chose to share that information with others.

On all of the return visits to Cyprus the researcher spent time living with Turkish Cypriot families and observing their day-to-day activities, such as grocery shopping or visiting family and friends. The researcher was able to be immersed in the culture and 
was included as one of the family. The families included the researcher in all aspects of their daily lives, including meal preparation, car repairs, home maintenance, health issues, visits to neighbors, even relationship problems, and communication issues with teenage children. This daily interaction with the Cypriots gave the researcher a unique insight into their culture and values, and their perception of the Cyprus problem.

The idea that one's own personal perception affects what you are able to hear, learn or see, was highlighted and reinforced time and again during those observations and from the interview process. In the spring of 2007, the researcher completed the informal interview process with 12 Cypriots. The subjects came from all walks of life: teachers, reporters, health care providers, writers, and business owners. Included in the interviews were six Greek Cypriots, and six Turkish Cypriots. There were four Greek Cypriot men and two Greek Cypriot women in addition there were three Turkish Cypriot men and three Turkish Cypriot women. The interviewees were originally part of the citizen's peace movement during the 1990's; they had trained with Benjamin Broome and others such as Louise Diamond, in the techniques of conflict resolution. They had attended many training sessions and had in turn helped to train many others in conflict resolution skills.

They were chosen as a group who had a great deal of motivation toward the Cyprus solution and who worked together for many years in the past. They had been arranging meetings to work on the peace process before crossing the Green Line was even allowed. They were required to obtain special permission to cross the Green Line and meet; sometimes at the last minute the leaders would not allow it. These courageous 
Cypriot citizens continued to work on different projects, despite persecution by their fellow citizens. They were called traitors, and some even received death threats. The researcher was told many stories about the difficulties they endured while continuing to work toward peace, yet they persevered.

The process for setting the appointments for the interviews was in itself a learning experience. The researchers first attempts to arrange interview appointments by phone or email were largely ignored. As the days went by and the departure date back to the states was getting closer, the decision was made to ask one of the Cypriots for help with coordinating the interviews. This proved to be very successful, and taught the researcher that an outsider will not get the same response as an insider will get. As a friend and fellow Cypriot, the interviews were granted almost immediately.

The interviews consisted of three main topics, with four or five specific openended questions designed to encourage dialogue. The three main topics on the questionnaire were: The Opening of the Check Points: The Referendum and the Annan Plan: The European Union Membership. The complete questionnaire can found in the appendix. The goal of these questions was to gain a better understanding of the perceptions of the Greek Cypriot and Turkish Cypriot and to explore what influenced those perceptions.

The researcher chose to take notes instead of using a recording device in order to keep the conversation more natural and flowing and to prevent the inhibitions that can arise when people know they are being taped. The interviews were conducted in a variety of locations based on the convenience to the person being interviewed. A copy of 
the questions that were asked was given to each person at the beginning of the interview. The researcher took notes as they spoke, and asked for clarification if something was unclear. Also noted was the person's compliance or frustration with the interview questions and these observations were documented as well.

The researcher chose a qualitative approach that views social phenomena holistically. Qualitative research aims to get a better understanding through first hand experience and to understand how the participants derive meaning from their surroundings, and how their meaning influences their behavior. Observation is used in qualitative research because it lets the meaning emerge from the participants. As with all objective research the information gets filtered through the personal lens of the researcher using his or her own personal history and educational background. That could be interpreted as perspective. The researcher must remain aware of how that may affect the study. Qualitative research is a multifaceted, interactive and ever-evolving methodology (Creswell, 2003).

To better understand how Cypriots on both sides of the Green Line saw those three events and how those events continue to affect Cyprus, it was essential to be immersed in their lives and culture. To live, and eat, and participate in everyday life created the possibility of seeing through their eyes and seeing how past experiences influenced new information given to them. The challenge as a researcher who is living and participating in the daily lives of people is to remain unbiased. It is a great challenge to remain attached to the group to have a better understanding, while still remaining somewhat detached from the group. The intimate setting allows for very personal insight 
but the drawback is that the researcher can lose perspective because they are too close to their subjects. It is a balancing act that seeks immersion, while remaining distant and detached. 


\section{Chapter Four}

\section{Historical}

Pearl Buck said, "If you want to understand today, you have to search yesterday". But what if each person sees yesterday differently? How then do the Cypriots understand today when they see the past in different ways depending on if that person is a Greek Cypriot or a Turkish Cypriot? The Greek Cypriots and Turkish Cypriots each have their own version of Cyprus' history (yesterday), how does that effect their perception of currents events (today)? The following brief history of Cyprus will offer further evidence of events that impacted the Greek Cypriot and Turkish Cypriot perceptions.

Anastasiou (2007) presents a summary of Cyprus history from British rule through Cyprus entering the European Union:

...the Cyprus problem had gone through significant changes in its specific structure, as it moved from the British colonial era, to independence in 1960, to the Greek coup d'etat and Turkish invasion of 1974, to the physical segregation of the GC and TC communities, to the secession of the Turkish Republic of Northern Cyprus (TRNC) in 1983, to the integration Cyprus into the EU in 2004 while remaining ethnically divided (p. 190).

Hannay (2005) asserts many rulers have controlled Cyprus prior to its independence. "The story of Cyprus, from classical times down to its independence in 1960, was one of domination by outside powers" (p. 1). Hannay argues that this domination by others throughout the history of Cyprus has left a permanent scar on most of the Cypriots. He observed that the Turkish Cypriots and Greek Cypriots have the feeling that control of their own destiny is not up to them and that inevitably outsiders will decide their fate. Also noted was an overall lack of congruence in the history of Cyprus (p. 1). Much of what has been published about Cyprus is given to personal perception and that perception has changed how the events throughout Cyprus' history 
have been reported. One predominate influence on perception was nationalism.

It is suggested that nationalism was a catalyst for the Greek Cypriots to seek enosis (union), and the Turkish Cypriots to seek taksim (partition) during the anticolonialism struggle in the 1950s. Anastasiou (2008 a) explains that, "The logic of each side's nationalism entailed a more or less permanent perception of the other ethnonational community as the enemy" (p. 27). The Greek Cypriots and Turkish Cypriots nationalistic view inherited from their motherlands fueled the quest for enoisis and taksim. Hannay (2005) points out, “The last decade of colonial Cyprus (1950-60) was a period of turmoil and violence on the island. Many of the dragons' teeth of the subsequent dispute were sown during that period" (p. 2). This was the beginning of the quest for enosis.

Archbishop Makarios was the leader of the Greek Cypriots toward enosis. He was the head of the Greek Orthodox Church in Cyprus and therefore, remained virtually unchallenged in his quest for enosis among the Greek Cypriots. As Makarios began to realize that enosis was not attainable, given the attitudes of both Greece and Turkey, the plan was then reluctantly switched to that of independence.

During the 1950's, the Greek Cypriots and Turkish Cypriots were having some struggles with each other, which were being encouraged by the British. Hadjipavlou (1993) references Pollis (1973) in regard to British motivations, "During this period, the British politicized the communal differences between the Greeks and Turks of Cyprus to serve their own strategic interests in the Middle East" (p. 343). Fueled by nationalism, the communal differences were encouraged by the British. This movement toward a separation was creating more of a division of ethnic groups and increased hostility toward one another.

Anastasiou (2008a) explains that:

By the year 1959, Greece, Turkey, and Britain had agreed to a settlement of the Cyprus problem. Cyprus was to be neither united with Greece, nor 
ethnically partitioned. It was to be established as an independent, bicommunal republic, whose sovereignty and territorial integrity was to be guaranteed by Britain, Greece, and Turkey (p. 94).

The London-Zurich Agreement consisted of three treaties: The Treaty of Guarantee, the Treaty of Alliance, and the Treaty of Establishment. The Treaty of Guarantee, prohibited union with another state and secession of Cyprus. It also named Turkey, Greece and the United Kingdom as the guarantor power. The Treaty of Alliance, allowed for a small military force, composed of a specific number of Greek and Turkish Cypriots. This treaty never came to pass. The Treaty of Establishment, allowed the United Kingdom to occupy and control two sovereign bases in Cyprus. These Treaties were not agreeable to all of the Cypriots.

Hadjipavlou (1993) refers to Xydis (1967) in regard to a settlement, “A compromise settlement (the London-Zurich Agreements) was reached in 1959 by Britain, Greece, and Turkey granting Cyprus a limited independence" (p. 343). At the time, it was seen as a concession by many, not what the Greek Cypriots and Turkish Cypriots truly wanted. Many thought the settlement was imposed on them without enough consideration for what the Greek Cypriots and Turkish Cypriots had been through.

Hadijipavlou (1993) states, "The 1960 settlement was basically imposed on the Cypriots by the three outside interested powers, without regard for local realities and social-psychological needs and concerns" (p. 343). Hadjipavlou (1993) Furthermore, there was great pain; stereotyping, misperception and distancing that occurred during the 1950 's struggles that were never addressed. The new constitution of 1960 only served to exacerbate those feelings and to encourage further distrust, as well as present a more definite separation of the ethnic groups. The preceding statements convey the perception that outsiders imposed their will on the Cypriots without much consideration.

The 1960 settlement was viewed by some as the answer, and by others as only encouraging the existing problems in Cyprus. Some saw it as being imposed, while 
others viewed it as independence. Hannay (2005) refers to The London-Zurich Agreement, "This potentially dysfunctional set of arrangements lasted for only three years before a major crisis derailed it. In 1963 the Turkish Cypriots withdrew from participation in the institutional structures of the state" (p. 4). Hannay suggests the Turkish Cypriots withdrew due to a dispute over fiscal matters. Hannay feels the Greek Cypriots viewed that as another way to disrupt the workings of this new system and possible push for partition of Cyprus. Tensions were rising in Cyprus and on an international level.

During the 1950's on an international level there were significant developments occurring. Anastasiou (2008 a) references Woodhouse (1968) and summarizes the developments:

In Europe, the cold war between the eastern and Western blocs was reaching its peak, while in Southeast Asia, the bloody Korean War had erupted, and the Vietnam conflict was going through its incubation phase. The Warsaw Pact and NATO had been fully established, with both Greece and Turkey invited to join as full NATO members in 1951 (p. 93).

Anastasiou goes on to say that the fear from the Cold War gave Greece, Turkey and Britain the motivation to seek connection with that of a Western Alliance. Turkey and Greece both came to view the benefits of cooperation with NATO far outweighed the argument over Cyprus. The international events and political influences impacted Cyprus in many ways and should be taken into account during the process of the conflict analysis of Cyprus to have a complete picture.

During the time period from 1963-1974, there was significant loss of life and property for both the Greek Cypriot and Turkish Cypriot communities caused by two separate conflicts. Following are four quotes. These quotes represent the perceptions of 
four people in regard to the time period 1963-1974 in Cyprus. Particular attention to how these individuals describe the situation should be given in order to gain insight to how similar and how opposing the perceptions can be in Cyprus. Some of the influences on perception include lived experience verses knowledge acquired from others.

Dr. Ozcelik, was born after this time period, he gives the following account:

During the end of the 1963, the intercommunal violence caused an imminent threat for the stability of the island. Nicosia (Lefkose), the capital of the Republic, became a battleground and physical segregation of the two communities intensified. Between 1963 and 1974, the Turkish Cypriots were forced to live in enclaves on their own in overcrowded slum conditions (p. 3).

Since March 1964 the United Nations (UN) peacekeeping troops have been in Cyprus. The area that divides the island is referred to as the buffer zone or the Green Line. The UN peacekeepers remain on the Cyprus still today and it is considered one of the longest peace keeping missions.

Volkan (1997) a Turkish Cypriot who was living in the United States during 1963-1968 time reports:

Between 1963 and 1968, Cypriot Turks were forced by Cypriot Greeks in enclaves under subhuman conditions and eventually occupied only 3 percent of the island, instead of the 35 percent they had previously owned. They became caged prisoners, surrounded by enemies (p. 95).

Volkan suggests that by 1968 the political climate had changed enough that the Turkish Cypriots were allowed to move out of the enclaves.

Hannay (2005) suggests the Turkish Cypriots chose not to participate in the institution of the recently formed Republic of Cyprus for other reasons besides a dispute over fiscal matters. Additionally security for Turkish Cypriots had become a concern and 
there were more disagreements between the Greek Cypriot and Turkish Cypriots leading up to 1964:

From this time on the security situation deteriorated steadily, with extensive harassment, particularly of Turkish Cypriots by Greek Cypriots and of Greek Cypriots by paramilitary nationalists, with numerous atrocities committed by both sides and with the much less numerous Turkish Cypriots tending to abandon their houses scattered in villages and towns where Greek Cypriots were in a majority and to group themselves together in enclaves where they could better defend themselves (p. 4).

Hannay suggests the Turkish Cypriots were inclined to "group themselves together in enclaves", as a way to better protect themselves. The language used would imply it was by choice that the Turkish Cypriots moved into enclaves. In contrast both Ozcelik and Volkan who use antithetical language to describe the situation; "the Turkish Cypriots were forced to live in enclaves". The preceding language would indicate lack of choice in regard to moving into enclaves. The researcher would like to highlight how different the perceptions are of the same time period as evidence of how the past influences each persons perception in a unique way. The theme of this paper is to illustrate how the perceptions of the Greek Cypriots and Turkish Cypriots have been effected by past negative events. Many would agree that the negative influence of nationalism on the Turkish Cypriots and Greek Cypriots was truly one of the largest contributing factors to the hostilities that broke out in 1963-1964.

Anastasiou (2008 a) shares the following about nationalism and the influence on perception:

Following Turkey's rejection of the proposed constitutional amendments and its threat of intervention, inter-communal violence broke out in 19631964. Even prior to these incidents, the TCs had been alarmed and mistrustful of GC nationalist intentions, just as the GCs had been strongly 
suspicious of TC nationalism and it partition-focused agenda. With the first violence, the TCs decisively broke away from the government (p. 96).

Both the Greek Cypriots and Turkish Cypriots had deep suspicions of each other's motives. Anastasiou (2008 a) goes on to explain more thoroughly, "In both cases, the nationalist vision of a mono-ethnic state was at work as the hidden, motivating force behind each side's perspective and objectives" (p. 97).

In 1974 more hostility and sadness ensued in Cyprus. The research endeavors to illustrate that everyone has a past through which all new information is filtered. The main point is how does conflict effect a person's perception.

Several countries were engaged either indirectly or as in the case of Turkey and Greece more directly during 1974 in Cyprus. Greek Cypriot professor Harry Anastasiou (2006) gives a timeline of events in Cyprus and describes what transpired:

Endorsed by the United States, with real and imaginary scenarios that were thought to serve western strategic interests in the region, the Greek junta, joined by EOKA B, launched a bloody coup in Cyprus on July 15, 1974, ousting Makarios and his government (Stern, 1977). On July 20, 1974, following a mere few days of Greek right-wing dictatorship, Turkey invaded Cyprus. Within a week, the civil war among the Greeks in Cyprus suddenly exploded into an inter-state, ethno-national war, involving the invasion of the Republic of Cyprus by Turkey's all-powerful army (p. 93-94).

Ergun, Cakici M, Cakici E. (2008) the following quote is from a scientific article presented at the Near East University Psychology Department, in north Cyprus:

The second wave of displacement came in July-August 1974. When the military junta of Greece removed the legal president, Turkey intervened in Cyprus in July 1974. It is reported that 180,000 to 200,000 Greek Cypriots fled to the south and approximately 50,000 to 60,000 Turkish Cypriots, many of whom had been displaced before, escaped to the north (p. 21). 
The northern part is also known as the Turkish Republic of Northern Cyprus (TRNC) that is the area that most Turkish Cypriots still live today. The reference to the "legal president" is referring to the first president in Cyprus Archbishop Makarios.

Maria Hadjipaviou (1993) a Greek Cypriot shares the following perspective about 1974:

This series of events led to the 1974 Greek-junta-engineered coup against Makarios and the subsequent invasion by turkey allegedly to 'restore constitutional order' on the island, which has been defacto partitioned ever since. Thirty-six percent of Cyprus' territory came under Turkish military control, and one third of the Greek Cypriots fled to become refugees in their own country (p. 344).

The defacto partition refers to the north or the TRNC that is not recognized by the Greek Cypriots as a legitimate state. Turkey is the one and only country to recognize the TRNC.

There have been many negative influences that have had an adverse impact on the perceptions of the Greek Cypriots and Turkish Cypriots. The partition of the island creating the north that is referred to more commonly as the TRNC by Turkish Cypriots or as the Occupied North by the Greek Cypriots is one of those influences. The two major times of conflict in 1963-64 and 1973-74 have destructively impacted perceptions as well.

In Cyprus, that is part of the issue with perception: The issue of collective memory and large group identity. The large group identity creates cohesiveness among the Greek Cypriots and Turkish Cypriots that encourages each community to remain in the past and not let go of it easily. Volkan (2008) gives a revealing illustration of large group identity:

Think of a man - let's say he is German — who is an amateur photographer. If he decides to stop practicing photography and take up carpentry, he may call himself a carpenter instead of a photographer, but he cannot stop being a German and become French. His Germaneness' is part of his 
large-group identity, which is interconnected with his core individual identity, his subjective experience of his self-representation. From a study of massive traumas at the hand of others. Retrieved from (http://www.vamikvolkan.com/Massive-Trauma).

In Cyprus each community has their own large-group identity of either Greek Cypriot or Turkish Cypriot, there is not a strong identity connection to being a "Cypriot".

There are many casualties of protracted conflict, physical loss of life, or one's own personal construct of distortion and enmity of their neighbors (in the case of Cyprus). Barash (1994) suggests the following, "Thus, one of the underlying functions of groups is to identify members of other groups as different from themselves. It is tempting to say that they 'misidentify,' since they exaggerate any existing differences, partly in the service of getting a firmer grip on who they are themselves" (p. 89). To an outsider the similarities between the Greek Cypriots and Turkish Cypriots are much more noticeable than the differences.

Freud refers to the tendency of people to focus on the small differences that distinguish one group from the other as the "the narcissism of minor differences". The Greek Cypriots and Turkish Cypriots in many ways see themselves as entirely different than each other. Barash (1994) gives us another way to look at it, “...perhaps because it is only by having a clear sense of them that we can get a clear sense of $u s^{\prime \prime}$ (p. 90). By placing the focus on the differences (even if there are more similarities) it remains much easier to not notice all the similarities and therefore to identify with your own group which more like you.

Mehmet Yashin (2001) is a Turkish Cypriot poet who reflects on the Greek Cypriots and Turkish Cypriots in Cyprus: 
When I was a child I used to wonder

If our Greek neighbours cat

Was also Greek.

One day I asked my mum

And she said cats were Turkish

Dogs were Greek

And dogs attacked the kittens.

Much later one day

What should I see?

Our cat was eating

Her own kitten.

This concept of one's own identity originating from not being like them has been passed on generationally in Cyprus. The younger generation who did not even go through the trauma and conflict during 1963-1974 has had the burden passed onto them to carry it forward. There has been a history, which included much pain and suffering for both the Greek Cypriots and Turkish Cypriots, and more recently the inability to move forward to a solution in Cyprus.

The hypothesis that the past injustices, which both the Greek Cypriots and Turkish Cypriots participated in, have potentially clouded the sound judgment of the future is essential to the understanding of chapter five. The subsequent chapter reviews how the Turkish Cypriots and Greek Cypriots responded to the interview questions. 


\section{Chapter Five}

\section{Interviews}

First, a brief overview of who was chosen for the interviews, and a little about their backgrounds. The decision to choose these participants was in part based on their previous training in conflict resolution and other problem solving strategies they practiced in Cyprus. The people interviewed were part of a bi-communal group who worked together on the Cyprus problem for many years during the 1990's, before the

checkpoints opened. Still, today many of them continue to work toward a solution, and try to remain hopeful. They continue to use many of the strategies and principals that were practiced during the 1990's. In Addition, new methods have been added to help continue move the peace process forward.

The bi-communal approach works to include parties from both the Turkish Cypriot and Greek Cypriot communities to participate in activities that will encourage peace. The basic principles include; participation of both communities as equals; activities that encourage a broader understanding between Turkish Cypriots and Greek Cypriots, with the goal of gaining a better understanding of the past and a clearer plan for peace in the future.

Some of the more common activities that were implemented to discourage enmity between the Cypriots were problem solving workshops, bazaars, bi-communal choirs, and concerts that brought both the Turkish Cypriots and Greek Cypriots together. This type of direct interaction allows for people to meet face to face, and begins to dispel 
many of the myths, and stereotypes that have been created throughout the years of separation.

As a result of years of separation with little or no contact it was easy to perpetuate the myths through the media and educational system. Without the means to verify the information given to them about the other side, the other side had become the enemy for many Greek Cypriots and Turkish Cypriots. They had become the monsters, who were not to be trusted. According to Broome (2005) "It is more difficult, following a pleasant conversation with a fellow Cypriot, to continue spreading hatred" (p. 22). Once the opportunity was available for direct contact it became more difficult for the Greek Cypriots and Turkish Cypriots not to question the sentiment of their leadership. It also initiated and encouraged more independent thinking for both the Greek Cypriots and Turkish Cypriots. As there was more contact, there was more dialogue, and more opportunity to work toward a solution for Cyprus.

The people interviewed for this research were from a bi-communal group of 15 Turkish Cypriots, and 15 Greek Cypriots. This group was trained during 1994-1995 in a process referred to as Interactive Management, as a means to develop a strategy for peace building in Cyprus. As Broome (2004) describes this process has three stages: (1) analysis of the current situation (2) goal setting for the future and (3) development of a collaborative action agenda (p. 25). The discussion and sharing of individual ideas in relationship to other ideas was the foundation for change. Broome (2004) describes shared perspectives "Both Greek Cypriots and Turkish Cypriots developed shared perspectives on issues they originally viewed quite differently, and they developed a 
deeper understanding of the importance of certain issues to the other community" ( $p$. 206-207).

In the beginning, the Turkish Cypriots and Greek Cypriots had to work separately; eventually they were given permission to meet in the Buffer Zone. At times, they would have a meeting planned and the permissions in place, but when it came time to cross the permission was denied. It was very frustrating for them at times, but they persevered despite their frustrations and the many obstacles. It is important to remember that this was during the time when the checkpoints were still closed and crossing was not allowed yet.

What this group achieved was considered pivotal by many in the peace movement in Cyprus during the 1990's and forward. Broome (2005) describes some of the activities of the peace group:

This group produced a systems analysis of the obstacles to peace-building efforts in Cyprus, created a 'collective vision statement' for the future of peace-building activities in Cyprus, and developed a plan of activities that would guide their work over the following two to three years. The latter consisted of fifteen projects, including workshops, presentations, training programs, and other events (p. 26).

The interviewees were chosen from this group to hear their perspective on the situation in Cyprus. The goal set forth by this paper is for the reader to see it through their eyes, their perspective.

Papadakis (2005) shares what he learned as a child. "We grew up thinking that Greeks and Turks were opposites; they had nothing in common" (p. 32). The preceding quote is very telling of how many Cypriots feel in Cyprus. Some Turkish Cypriots and 
Greek Cypriots have made every effort to learn about each other and have participated in conflict resolution workshops with the goal in mind of bringing peace to the island. Many of those brave people went to great risks to try and make a difference. Those who persevered despite being called a traitor, losing family, friends, losing jobs, even enduring death threats those are the silent, unnoticed heroes in Cyprus. Through the research process there were many personal stories shared by both Greek Cypriots, and Turkish Cypriots regarding the toll that those years of sacrifice took on their families. Both the Greek and Turkish Cypriots who worked towards a solution sacrificed a great deal during the 1990's.

Not all Turkish Cypriots and Greek Cypriots stayed in Cyprus during those years of conflict. Some moved to other countries and returned to Cyprus much later when the situation was considered more stable. Following are the comments from one individual during a conversation in March of 2010. A Greek Cypriot woman was asked, "What is it going to take for things to change in Cyprus? Why does it feel as though the Greek Cypriots and Turkish Cypriots will not let go of the past and move forward"? She responded, "They don't want to let go of the past; they want to hang on to it". She went on to say, "It is as though it would be disrespectful to the people in Cyprus who suffered during the conflict not to continue hanging on to the pain and suffering. Also they are each expected to pass it on to the next generation". This woman was a Greek Cypriot, who was born in Cyprus but left before the conflict. She had lived in many different places around the world for part of her childhood, and then again as an adult. This is what she has observed now that she is once again living in Cyprus for the last several years. 
Volkan illustrates the process of passing the pain onto the next generation as described by the Greek Cypriot woman:

Transgenerational transmission is when an older person unconsciously externalizes his traumatized self onto a developing child's personality. A child then becomes a reservoir for the unwanted, troublesome parts of an older generation. Because the elders have influence on a child, the child absorbs their wishes and expectations and is driven to act on them. It becomes the child's task to mourn, to reverse the humiliation and feelings of helplessness pertaining to the trauma of his forebear (p. 43).

The research indicates that some of the younger generation, who were born after the two major conflicts in Cyprus during the early 1960's and mid 1970's, still maintain an attitude and perception similar to that of their elders. Broome (2005) suggests the education has an influence, "Generally, both Greek Cypriots and Turkish Cypriots are very selective in their memory of past events and their description of these events is far from objective. The past has been distorted beyond recognition by the educational systems and political propaganda of both sides" (p. 83). The educational system encourages this fallacy to the children through the use of one-sided history books.

In March of 2008 the researcher was invited to observe and participate in a Youth Encounter Project (YEP) held in Larnaca, Cyprus. The purpose of the event was to determine how much the Turkish Cypriot and Greek Cypriot youth know about each other; to give a place and opportunity, for them to get together and learn about each other and provide a safe space to ask questions and seek information from on another. It was interesting to learn that many of the youth from both sides of the island, Greek Cypriot and Turkish Cypriot never had any personal contact with each other prior to these YEP events. 
After the Greek Cypriot and Turkish Cypriot youth spend time together participating in various group activities, many are surprised to learn how similar they are and how much fun they have together. Many are very surprised to find that the other is not the enemy; really they have the same teenage problems as themselves. Whether they are Turkish Cypriot, or Greek Cypriot, they have similar struggles with school, and parents, and all of the typical challenges of being a teenager. It is the hope of some who work toward a solution for Cyprus, that the youth will be that solution. Bringing the young people (Greek Cypriot and Turkish Cypriot) together and by educating them in the ways of conflict resolution, this could conceivably help to achieve a peaceful solution in Cyprus. The youth will be the future leaders of Cyprus and the decision makers for what directions to go.

Cyprus will need to continue to grow and expand into the wider global market and with the help of the European Union this is possible. But living in the past will hinder the forward progress for Cyprus. Broome (2005) suggests moving forward, "Cyprus and its people cannot afford to remain stuck in a painful and dysfunctional past. It is time to move toward the future and join the multicultural world of which all Cypriots are members" (p. ix). As a member of the European Union, Cyprus has new opportunities available as part of the greater European community. How will they see these opportunities and how will they choose to use them?

All of the negative and distorted history in Cyprus has influenced the perceptions of the Greek Cypriots and Turkish Cypriots and altered their perception of new information. When new information is being filtered through a history of conflict and 
pain there is a common tendency to be defensive and suspicious. Anastasiou (2007) explains:

As mistrust and suspicion begin to affect the communicative process, all information received from and exchanged with the other side is cast and deciphered through a perspective that renders the search for ulterior motives, for tricks and machinations in the other side's intentions as the primary way of reading, hearing and responding to the other party (p. 63).

The idea of how mistrust and suspicion effects perception of the Greek Cypriot and Turkish Cypriots was the question in mind as the interviews were being conducted.

The three main interview topics are; the opening of the checkpoints; the referendum and the Annan plan; European Union membership. There were five questions asked about the opening of the checkpoints, the referendum and Annan Plan and six questions about EU membership. All of the Turkish Cypriots and Greek Cypriots interviewed were asked the same questions in the same order. The actual questionnaire can be found in the appendix.

Summaries of the responses to the questionnaires have been divided into five categories; dispelling myths; opportunity; discouragement/sense of hopelessness; inequality; and perception. The five specific categories were chosen because those were the main themes found throughout the interview process. The answers from each person interviewed were not consistent, which suggests a process of categorization. The five categories helped to facilitate in the organization of the information gained from the responses.

During the interviews what was noted was the variety of answers given to the same interview question. As the questions were asked it became evident that each 
answer was contingent on that persons past experiences without doubt. Those past experiences may include; more or less education, travel outside of Cyprus, direct experience with personal loss due to the conflict, the age of the person, a combination of other circumstances and personal attributes.

\section{Opening of the Checkpoints}

Free movement came as an unexpected event for most of the Cypriots. Anastasiou (2007) illustrates the opening of the checkpoints:

On April 23, 2003, shortly after the collapse of The Hague talks, an extraordinary event took place in Cyprus. With Turkey's consent and prodding, the Denktash administration of the TRNC decided on a partial lifting of restrictions on citizen movement across the great divide of the 'green line'- the ethnically segregating boundary that had become fossilized over 29 years along the 1974 cease-fire line" (p. 194).

The partial opening allowed for movement about the island for those who wished to go see their villages and homes that had been left behind.

\section{Dispelling Myths}

During the years of separation many myths arose for Greek Cypriots and Turkish Cypriots. One Turkish Cypriot stated, “The Greek Cypriots will finally see we are not monsters", and others made comment, "They will see we are not the enemy". Barash (1994) gives an illustration of how a knife needs a whetstone to become razor sharp, so have people become dependent on a worthy opponent/enemy. "Many lives are given shape and substance by their orientation toward an enemy" (p. 105). According to Barash, at times having an enemy allows the person to know what they are not.

A Greek Cypriot woman interviewed commented that people had created a myth 
about the other side, so to get a chance to visit, and see it, was very attractive. Another mentioned, "There was desire, and then a reality test, what it was, and what it is".

This following illustration could be dispelling myths or perception. One Greek Cypriot interviewed shared a story about a fellow Greek Cypriot who had to flee his home during the conflict. This Greek Cypriot for all the years of separation before the checkpoints were opened, he had been imagining what his home that he had left behind on the other side looked like. He remembered it as a "big" and "beautiful" home and he missed it very much. But when he finally went back after the checkpoints opened to see that house that he missed so much, what he saw, was it was not as big, or beautiful as he had imagined it for all of those years. The house he currently lives in now in the south was actually much bigger and nicer.

\section{Opportunity}

Many of the Turkish Cypriots and Greek Cypriots interviewed described the opening of the checkpoints as "very positive". They also spoke of people helping each other cross to the other side. Some described the opening of the checkpoints as an opportunity, because now people could mix and interact with each other. Others who were interviewed saw the opening as an obstacle because now there is "no need to mix". One Greek Cypriot stated that this was a "missed opportunity", that the opening of the checkpoints could have been translated into a new institutionalized program or center to encourage interaction between the Greek Cypriots and Turkish Cypriots. 


\section{Discouragement/Sense of Hopelessness}

Some interviewed shared how they had imagined their homes and villages for all those years, and then to finally see it, was terribly disappointing. One person reported that some of the people they knew who crossed after the opening required therapy. Therapy, because they were so sad when they finally saw their homes and the house was not as wonderful as they had imagined it for all of those years. The researcher was told that some of the Turkish Cypriots and Greek Cypriots chose to just live with the dream, to live with the memory of what was left behind, and they chose not to cross. One Greek Cypriot suggested that now that there is the opportunity to cross, no one is talking about a solution to the Cyprus problem and the Cypriots hope is fading.

\section{Inequality}

Many of those interviewed reported to the researcher that when the checkpoints first opened there were different standards required to pass through. It was explained to the researcher that the standard was dependent on whether you were a Turkish Cypriot or a Greek Cypriot and some felt this very unfair. One Turkish Cypriot said before the opening of the checkpoints they had heard for many years how wealthy the Greek Cypriots had become and that created a sense of feeling unwanted by the Greek Cypriots. Another Turkish Cypriot after crossing felt that the Greek Cypriots treated them differently and they felt the Greek Cypriots looked down on them.

\section{Perception}

One Turkish Cypriot gave this metaphor to describe the opening of the checkpoints, "The bride was not a virgin, and the mother-in-law is interfering". A Greek 
Cypriot suggested that opening the gates was not helpful and this statement was made, "Close the gates now, it is not helping because there is no solution". The opening of the checkpoints was viewed as an obstacle by one Greek Cypriot because it was done without first having a solution to the Cyprus problem.

Some Greek Cypriots and Turkish Cypriots in general wonder if it is even politically correct to cross. One Turkish Cypriot interviewed explained that their leadership suggested not crossing to the other side and some Turkish Cypriots have never crossed. Another Greek Cypriot shared that their brother had crossed once, and never again. The Greek Cypriot also said that Greek Cypriots do not spend their money in the North, and that more Turkish Cypriots cross than Greek Cypriots. Some Greek Cypriots have chosen not to cross and see no reason in the future that it will ever be necessary.

Broome (2005) provides this information in regard to crossings after the checkpoints were opened. "Within a few months it was estimated that three-quarters of all Turkish Cypriots had visited the south, many more than once, and that half of all Greek Cypriots had visited the north" (p. 225).

The last of the five questions in regard to the opening of the checkpoints follows, "Given the current conditions, do you think that the mixing of the two communities will contribute to the future reunification of the island or deter it"? One Greek Cypriot had the following comment, "Neither, people are pathetic. There are no groups organized to bring change, and there is a loss of hope or a feeling of not being powerful enough. Really what is reunification? It has very different meanings to different groups on both sides". Yet another Greek Cypriot interviewed saw the mixing as definitely helping 
because it gave the opportunity for Greek Cypriots and Turkish Cypriots to see how much they were alike. Another Greek Cypriot said that the problem is outside of Cyprus, that it involved Greece, Turkey, European Union, and the United States. While the researcher was in Cyprus the preceding comment was heard on several occasions. "If only everyone would just leave us alone we could get along fine. The Turkish Cypriots and Greek Cypriots do not have a problem getting along. It is the Turkish army and all the other countries who are creating the problems". That is what the researcher was told by many a Greek Cypriot and Turkish Cypriot, during many a conversation while in Cyprus.

Volkan offers a theory about identity, "Prejudice serves to differentiate one group from another; it helps people retain their group identity, which, in turn, supports their individual identity" (p. 113). In Cyprus there is unresolved prejudice between the Greek Cypriots and Turkish Cypriots and it certainly separates the two groups on many levels for different reasons.

During the fall of 2006, while living on the Greek side inside the walls of Nicosia, the researcher had the pleasure of meeting an American woman, which is not common in Cyprus. She was married to a Greek Cypriot, and they moved to Cyprus because her husband had struggled to find employment while they were living in the United States. This American woman ran a clothing shop inside the walls of Nicosia in the south on the pedestrianized street area. During the course of a very friendly conversation in English, she brought up that she had never crossed into the north. When the researcher questioned her as to why, she explained that she had been told not to cross by her husband and his 
family. The reason given to her was because you were required to sign a document acknowledging the "other side" as a legitimate state. The researcher had heard this before, several other times, from other Greek Cypriots. They would not cross because that could imply that the "other side" was a legitimate state, and they do not want to give any sort of recognition to the north, which claims to be the TRNC.

When the researcher shared with the American woman that she crossed almost daily and there was no such document required the woman was shocked. The researcher shared a little about how some Greek Cypriots do not want to cross, and will create a reason why you should not cross. That many have very strong feelings in support of not crossing. When the woman's husband walked into the shop, the researcher was introduced as an American staying in Cyprus. The woman told her husband that the researcher crossed frequently, and there was no document to sign, then his facial expressions changed. She also told him that the researcher had offered to let her go along with her to the north so she could see it also; he politely thanked the researcher but declined. That was the end of that conversation and it seemed to leave the wife very confused by the interaction that had just taken place. The researcher return a couple more times to see if maybe the woman was there to talk with, to follow up after that conversation, but she was never there.

During the researchers time in Cyprus there was a clearly negative attitude among some of the Greek Cypriots, in relation to crossing into the north. Many Greek Cypriots in the past held a belief that there should be no recognition of the Turkish north. Wolleh (2001) asserts, "The overriding rule of avoiding an 'implicit recognition' of the North 
makes a crossing for a Greek Cypriot into the Turkish Cypriot North very problematic. Avoiding any implicit recognition means that nothing should be done that could be interpreted as an indirect recognition of the other's legality as a state" (p. 26). There is an always-present concern of giving recognition to the north, which is referred to as "the defacto state". It is generally implied that to acknowledge the Turkish north in any manner, is to acknowledge that it is a separate state.

Following are four graphs that provide information in connection with the opening of the checkpoints. The United Nations Peacekeeping Force in Cyprus (UNFICYP) provides the following data and graphs. The four graphs include; frequency of crossing; reasons for crossing; has crossing changed your opinion of the people on the other side; and a cross-tabulation of crossing frequency with impact of openings.

Slide F.1 reflects the frequency of crossing and it indicates $49 \%$ of the Greek Cypriots crossed once or a few times and not anymore agrees with the researchers findings. Many of the Greek Cypriots say there is really no reason to cross other than to see Kyrenia. Also that $39 \%$ of the Greek Cypriots never crossed, which the researcher found during conversations that many have not, nor ever plan to cross in the future. This graph indicates that a very low percentage, $1 \%$ of the Greek Cypriots and $8 \%$ of the Turkish Cypriots cross frequently, and the researcher noted that the reason is to go a special destination such to see the mountains or the beach on the other side.

Slide F.2 indicates that the Greek Cypriots cross for two main reasons, 39\% cross for religious pilgrimages and $35 \%$ cross visit their old home or village. In contrast $42 \%$ of the Turkish Cypriots cross to enjoy shopping and 58\% to enjoy the countryside. 
According to the researcher those percentages are accurate except for there was very little or no discussion of anyone crossing for religious pilgrimages.

Slide F.3 asks if their opinion of the people from the other side has changed after crossing. For the Turkish Cypriots $63 \%$ say it hasn't changed compared to $41 \%$ of the Greek Cypriots. The researchers experience suggests that more Turkish Cypriots saw the Greek Cypriots differently in a positive way after crossing. 


\section{F.1 The opening of the Crossing Points}

Regarding the frequency of crossing to the other side, which of the following statements best reflects your own habits?

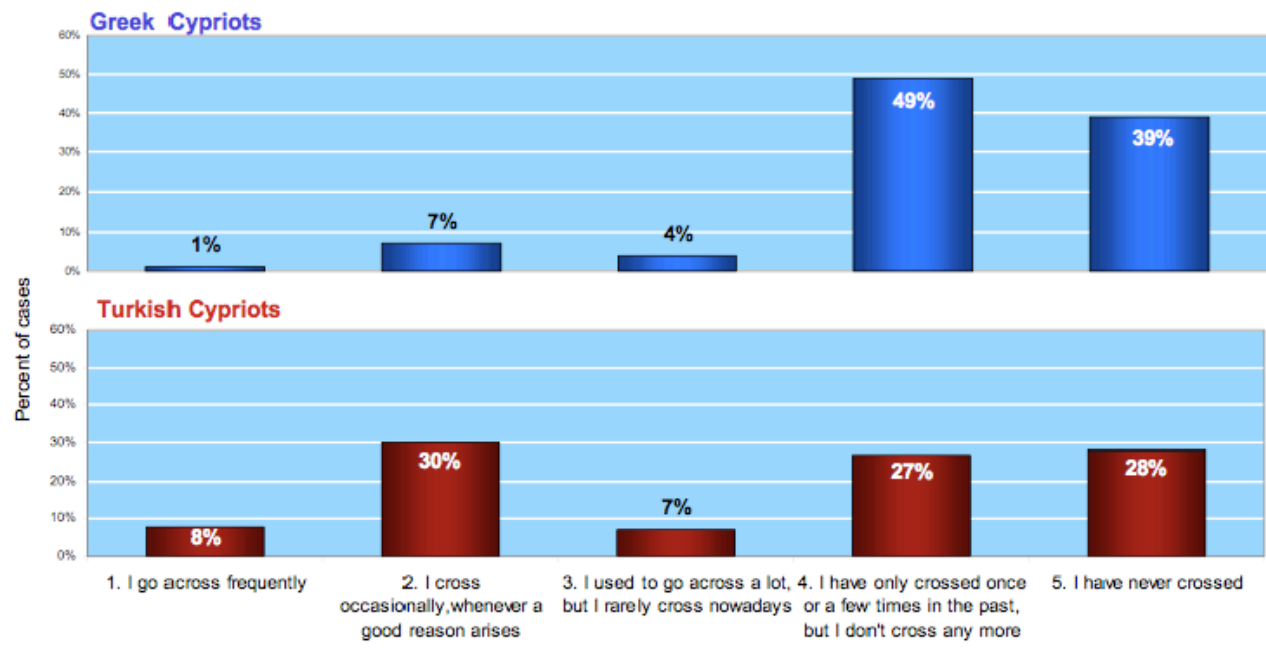

UNFICYP Survey - Pelling concucted 26 January - 19 February 2007 . Total number of face to face interviews: 1,000 with individual Greek Cypriot

s.2. The opening of the Crossing Points

Reasons for crossing

Turkish Cypriots

Greek Cypriots

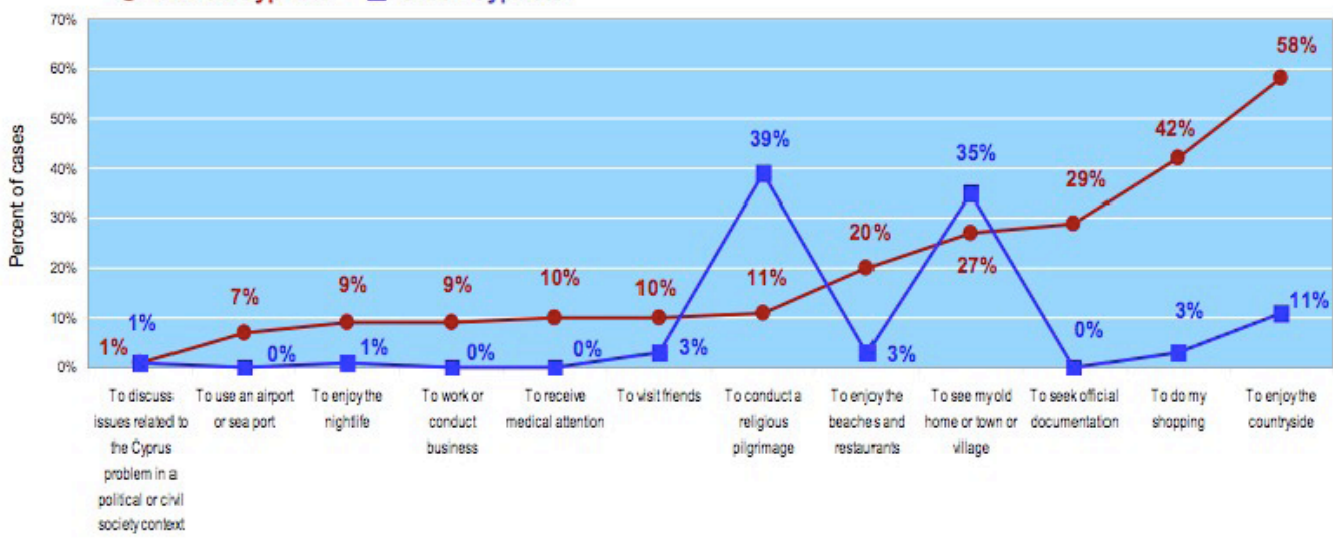




\section{${ }_{F .3}^{\text {sube }}$ The opening of the Crossing Points}

As a result of crossing the checkpoints, would you say that your opinion of people from the other side has changed?

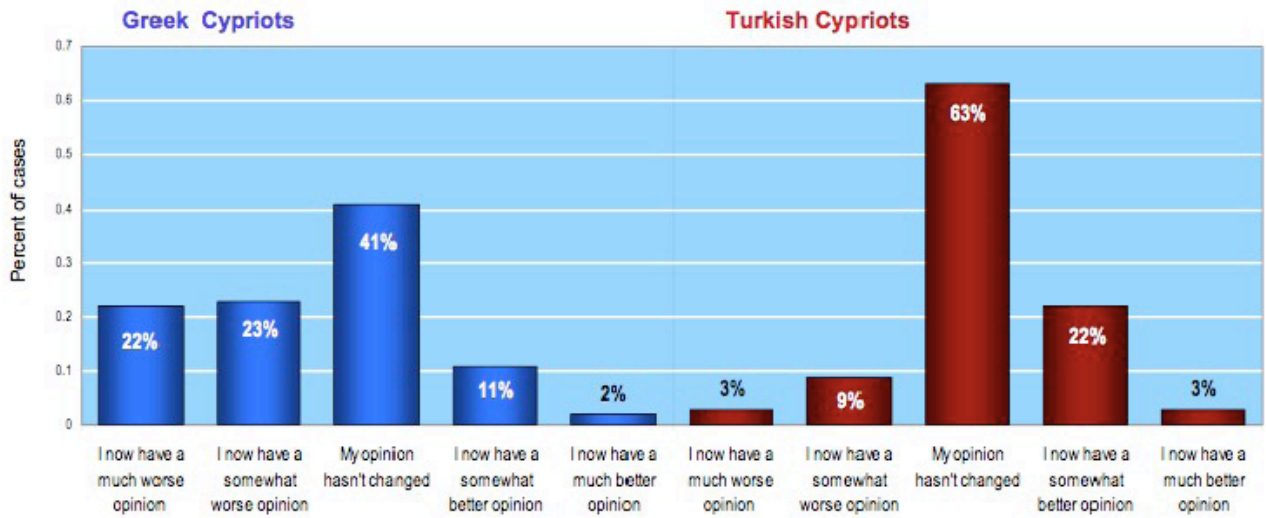

UNFCYP Survey - Polling conducted 26 January - 19 Febrary 2007 . Total rurber of face to face interniews: 1,000 with irdvidual Greek Cyprots.

\section{F.4 The opening of the Crossing Points}

Cross-tabulation of crossing frequency with impact of openings

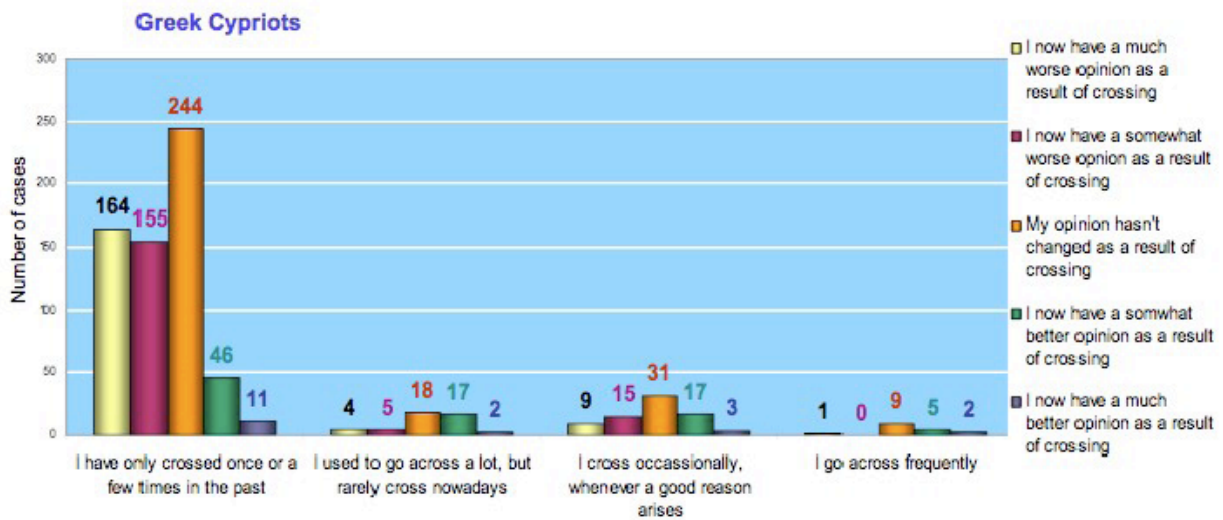




\section{Referendum and the Annan Plan}

On November 11, 2002, the UN launched what some have referred to as a historical proposal. "Basis for the Comprehensive Settlement of the Cyprus Problem". Anastasiou (2007) refers to the Annan Plan as, "The most elaborate and sophisticated proposal ever presented" (p. 191). The Turkish Cypriots showed their support for the proposed plan through many large rallies in the north prior to voting on the Annan Plan.

"The phenomenon marked a historic novelty in that it was the first time ever the TC community asserted its political voice above and beyond Denktash's secessionist agenda" (p. 192). One of the Turkish Cypriots interviewed stated, "the power of the people ruled for the first time ever in history".

\section{Dispelling Myths}

Under the topic of the referendum and the Annan Plan one of the questions was about the understanding of the plan for both Greek Cypriots and Turkish Cypriots. "How do you assess your community's understanding of the Annan Plan?” All of the Turkish Cypriots interviewed felt as though there was a great deal of coverage on the Turkish television with academic discussions every night. One Turkish Cypriot commented that it was necessary to go on a diet after voting. This was because they would bring a tray of food to eat while in front of the television every night, listening to the discussions about the Annan Plan.

In addition the Peace Research Institute Oslo (PRIO) had written and published a booklet to help people understand the Annan Plan that they used for more information. The Turkish Cypriots also indicated that they heard that in the south (where most of the 
Greek Cypriots live) they were misinformed, and the numbers in regard to population, property, and many other items that would have more of an impact on the Greeks had been manipulated as to make things appear differently then they really were.

Bryant (2004) reports that the Turkish Cypriots were well informed to vote on the Annan Plan. "Beginning with the 2002 announcement, Turkish Cypriots began a long, hard struggle to change their government, to gain the support of Turkey and to educate the electorate". For some of the Turkish voters the Annan Plan would require them to give some of the land they had been living on back to the south. "But even in those districts where thousands of Turkish Cypriots would have been relocated, the plan was approved with a resounding majority, for it would have meant a new state of certainty about the future" (p. 2). During the voting of the Annan Plan 65 percent of the Turkish Cypriots voted in favor of the plan.

However, on the Greek side when asked, the responses were unanimous that most Greek Cypriots did not understand the plan. They said the media attacked it, and manipulated the information to make it appear as though they would be giving up more than the Turkish Cypriots. In particular the Greek Cypriot felt that they had to give up most of their land that had been left behind when the forced separation was implemented. One Greek Cypriot interviewed said, "The people still don't even know they were manipulated", referring to the other Greek Cypriots. According to one Greek Cypriot when one of the television channels reported the truth, it was cut from the air.

Another Greek Cypriot indicated that they thought the plan meant going back home, and that the Turkish Cypriots thought it meant bi-zonal, bi-communal, bi-federal. 
Most Greek Cypriots agreed that they received misinformation, and they felt the leadership had emphasized certain parts for their benefit. Volkan (2004) suggests that when there are stressful situations that leadership will reactivate the chosen glories and traumas to create tension and fear among the people. That during those times the political leadership will focus on the losses and use it in their hate speech and propaganda against the enemy (p. 100).

Bryant (2004) suggests that because the Greek Cypriots were more focused on becoming one of the wealthiest European Union states, not as much effort was put into the discussion of the Annan Plan. "Up until the day of the referendum, polls showed that almost 70 percent of Greek Cypriots felt that they did not understand it, especially the complicated procedures for the return of refugees and restitution of property". Bryant goes on to say the media and church had a very large influence on the information that was to be made public on the Greek side. "The plan was presented to them in bits of propaganda and in the diatribes of the church, many of whose leaders condemned the plan as 'satanic' and threatened their flocks with damnation if they voted in favor"' (p. 2). The perceived benefits and deficiencies to the Annan Plan were very different, based on whether your information came from the Turkish Cypriots or the Greek Cypriots.

\section{Opportunity}

One Turkish Cypriot interviewed indicated that they might lose some physical property, but other aspects would make up for that. The general feeling among the Turkish Cypriots interviewed was that the Annan Plan was a good start in the right direction. Another Turkish Cypriot suggested the Annan Plan is the first step in the 
solution, a good starting point, not the answer, but part of the answer. Several Greek Cypriots interviewed agreed that the Annan Plan was an opportunity, not ideal, but perhaps the best possible plan at the time. One Turkish Cypriot said that the "power of the people ruled for the first time ever in history." Turkish people in the north took to the streets in protest, the NGO leadership had a large influence and civil society took a stand.

\section{Discouragement/Sense of Hopelessness}

One Greek Cypriot interviewed said the leadership created a sense of fear in the people, by focusing on things like the Turkish army. "Compromise is for traitors", was one of the popular slogans and allegedly the Greek president led this propaganda. Volkan (1997) suggests that past traumas can be suppressed and become dormant until an event arises where the leadership chooses to rekindle them. "For instance, a political leader may reignite a dormant group memory that affects collective thinking, perceptions, and actions. When such a shared mental representation of the original injury is reactivated, it may distort a large group's perception" (p. 46). The Greek Cypriots were encouraged to focus on what had been taken from them at the hands of the Turkish Cypriots and how little they were getting back. They were encouraged to focus on how unfair the Annan Plan was to the Greek Cypriots.

Some Cypriots, both Greek and Turkish believe "no solution is the solution", and others report that hope is very low since the Annan Plan did not pass. It was conveyed to the researcher that some of the people in Cyprus feel depressed because they feel as though they are trapped by their leadership's decisions; they feel as though what the people want does not matter. One Turkish Cypriot said that the people are more skeptical 
and afraid since the Annan Plan failed to pass.

\section{Inequality/Sense of Unequalness}

One Turkish Cypriot interviewed believed the Annan Plan would have been an injustice, because they believed that the Greek Cypriots would get to live in both the north and the south, but Turkish Cypriots would only be able to live in the north. The north would become integrated but the south would remain mostly Greek Cypriots according to how the Turkish Cypriots understood the Annan Plan. Many Greek Cypriots felt that the Annan Plan did not return enough land, and were adamant that the Turkish military must go. From the Greek perspective any plan that did not allow for those two very important factors was not going to pass.

\section{Perception}

One Greek Cypriot suggested the Annan Plan should return more land to the Greek Cypriots and another said that what was being offered the Greek Cypriot was an injustice, such a limited return of property. When asked what role did the leadership play in the outcome, one Greek Cypriot woman said, and this is a quote, "I don't give a shit". This person went on to say that the leadership was irrelevant. This person had very strong feelings about the situation and felt comfortable sharing those feelings with the researcher. They felt the leaderships only concern about the Annan Plan was how it would benefit the leadership not the people.

\section{European Union Membership}

Sommer (2005) describes the EU membership:

In legal terms, the whole of Cyprus is considered to be territory belonging to the EU after 1 May 2004, but the EU legislation is suspended in the 
North. The Greek Cypriots as the internationally recognized representatives of the whole of Cyprus, who as a matter of fact only represent themselves, have a voice and seat in all the EU institutions, while the Turkish Cypriots, who had voted for unification and EU membership, remain outside (p. 58).

\section{Dispelling Myths}

When asked questions during the interview in regard to becoming a member of the European Union the answers were varied. Some thought it was good for both the Greek Cypriots and Turkish Cypriots, and others did not. Some thought it gave the

power to the Greek Cypriots and isolated the Turkish Cypriots even more; others did not. Some thought it was going to be the solution and others thought it was creating more problems. Some thought that until the Turkish Cypriots were out of isolation things would not be different; others did not. There was not any theme, except for the lack of a theme.

The myth of joining the European Union creating a solution has collapsed. Though, some still have hopes that if the Greek Cypriots and Turkish Cypriots become more European, that in itself will help the situation and with the support of the European Union that the Cyprus problem will be solved.

\section{Opportunity}

Many of the Turkish Cypriots saw the European Union as being helpful and possibly being part of the solution; some saw it as neither. The Greek Cypriots saw the European Union as both helping and giving opportunities. One Greek Cypriot said, "Even if there is no solution, the gradual steps to conform to the European Union standards will gradually solve the problem". 


\section{Discouragement/Sense of Hopelessness}

One Greek Cypriot used a metaphor to describe how he has come to feel about the situation in Cyprus. This person shared that during the 1990's there was a sense of hope and excitement in Cyprus for a solution. However this Greek Cypriot feels that has changed now, and that people are discouraged now:

It felt like I was on a train, and I used to try and tell all the people on that train what was going to happen. I tried to warn them, I tried to tell them it was going to crash. But now I have decided to just go along for the ride also. I am going to just live my life, and if the train crashes at least I am having a good time along the way (interview notes).

\section{Inequality/Sense of Unequalness}

One of the questions asked about European Union membership was, "Has European Union membership improved or undermined Turkish Cypriots and Greek Cypriots relations? All the Turkish Cypriots interviewed were in agreement that the European Union membership had undermined the relationships between the Greek Cypriots and Turkish Cypriots except for one, who thought relationships, had improved. One of the reasons the Turkish Cypriots have negative feelings is because now they have to go through the Greek Cypriots any time they need access to the European Union. To the Turkish Cypriots this feels even more unequal because it feels as though the European Union has taken sides, and the Turkish Cypriots are still left in isolation.

Some Turkish Cypriots wonder if, in the future there could be potential problems in regard to Turkey entering the European Union because now both Greece and the Greek Cypriots have veto power. 


\section{Perception}

When asked the question, "Has joining the European Union been a positive or negative for the Greek Cypriots?" All the Turkish Cypriots interviewed agreed it was positive except for one. The reason given was that now the Greek Cypriots seemed to feel more secure, because now they had become part of a larger group. The Turkish Cypriots recognized that the Europeanization of Cyprus is helping to improve the standards for food, environment, human rights and democracy. The one Turkish Cypriot who perceived the European Union membership negatively expressed that the Greek Cypriots are using the membership to get what they want and believe they deserve. Further more that the Greek Cypriots are not following the rules set by the European Union.

When the Greek Cypriots were asked, "Has joining the European Union been a positive or negative for them?" They unanimously reported it as a very positive advancement. It was interesting though that most of the Greek Cypriots said it was positive for both the Turkish Cypriots and Greek Cypriots. The Greek Cypriots agreed with the Turkish Cypriots about the benefits, and one Greek Cypriot even admitted that yes, in fact, the Greek Cypriots were trying to take advantage of the European Union.

Subsequently, the Turkish Cypriots were asked, "Has joining the European Union been a positive or negative for the Turkish Cypriots?" None of the Turkish Cypriots interviewed said it was a positive or a negative, instead they said they were getting some benefit from joining. The Turkish Cypriots said that travel is easier now and there is more freedom of movement. They also appreciate that they are getting some help 
financially, but say it is not enough and it is not coming fast enough. Their frustration with how slow the promises are being fulfilled deepens their concern that perhaps they will not ever be fulfilled. The Turkish Cypriots also expressed concerns about the Greek Cypriots now having the right to veto.

The Greek Cypriots varied in their responses when asked, "Has joining the European Union been a positive or negative for the Turkish Cypriots?" One Greek Cypriot reported positive benefits for both because the European Union was fairer and now there were specific laws that must be followed. Several Greek Cypriots mentioned that they felt the Turkish Cypriots were feeling as though they are being punished. A comment made by a Greek Cypriot, "The Turkish Cypriots should not have been left out. We can't pretend, the Turkish Cypriots are still in isolation".

Sommer (2005) gives insight to the European Membership:

In legal terms, the whole of Cyprus is considered to be territory belonging to the EU after 1 May 2004, but the EU legislation is suspended in the North. The Greek Cypriots as the internationally recognized representatives of the whole of Cyprus, who as a matter of fact only represent themselves, have a vice and seat in all the EU institutions, while the Turkish Cypriots, who had voted for unification and EU membership, remain outside (58).

One Turkish Cypriot conveyed feelings about the Greek Cypriots, "Now they say they are European Union members which entitles them to more. Being a European Union citizen earns you respect, they see Turkish Cypriots as inferior". Turkish Cypriots have spent years with feelings of inferiority, in addition to living under an embargo. Bryant (2004) offers a perspective on the situation in Cyprus, "While Turkish Cypriots have lived the quotidian realities of a 'made-up state,' Greek Cypriots have lived the 
quotidian fantasies of recognition" (p. 6).

During the last 30-plus years, certain terms have been created to describe the north: "pseudo-state" that is run by a "so-called" president. During the researchers time in Cyprus these kinds of statements were heard many times. Though many may joke about these terms, the reality is that only Turkey and its residents recognize the northern portion of the island, which complicates daily life exponentially. 


\section{Chapter Six Analysis and Recommendations}

Anastasiou (2002) suggests there are two main component parts that have influenced the interactions and communicative process in Cyprus. "These are the longstanding impact of ethnic nationalism as a world and life view, and the collective

memory specific to the experiences of pain and injury in each community" (p. 581). If that is true, how does ethnic nationalism and the collective memory change the perception of (new) information given to Turkish Cypriots or Greek Cypriots?

\section{Opening of the Checkpoints}

One of the Greek Cypriots interviewed stated, "Close the gates now, it is not helping because there is no solution". Other Greek Cypriots interviewed mentioned that since they can cross freely now, the motivation to work on a solution has dissipated. Excluding those interviewed, some Greek Cypriots in general, feel unsure if it is even politically correct to cross though it is allowed now. In an article written by Constantinou and Papadakis titled, “Across the Green Line: Problems of 'Recognition', 2001, the authors analyzed the issue of giving recognition to the "other side" by crossing the Green Line. "One of the paradoxes of the Cyprus problem is that more contact between Turkish and Greek Cypriots is probably necessary to untangle the many issues separating them" (p. 1). That article was published in 2001, before the Cypriots were allowed to cross freely.

Prior to the opening of the checkpoints in 2003, in general some Greek Cypriots and Turkish Cypriots felt that if they could cross freely that would help the peace process. They believed the opportunity to cross freely and to interact with each other would help 
to dispel the myths that had been perpetuated throughout the years by the media and political leadership. For others the main issue was the concern of implying recognition by crossing. Some Greek Cypriots in general, both prior to the opening of the checkpoints and after, still hold fast to the belief that crossing into the north indicates recognition of the TRNC and refuse to cross. While living in Cyprus, during day-to-day activities these were the beliefs and feelings frequently conveyed to the researcher during many conversations with Greek Cypriots and Turkish Cypriots. Nevertheless, the Greek Cypriots and Turkish Cypriots interviewed when asked about the opening of the checkpoints, many saw it as a negative and not as an opportunity for a solution. Even though prior to the opening of the checkpoints they had seen it as a positive step toward the solution.

When crossing from one side to the other there is a procedure. The procedure varies depending on whether you are a Greek Cypriot crossing into the Turkish side, or a Turkish Cypriot crossing into the Greek side. There is also a different procedure if you are a foreigner with a EU passport, or a non-EU foreigner. Along with these procedures there are visual images that one must look at to cross to the other side. They are a constant reminder to both the Greek Cypriots and Turkish Cypriots of the pain, suffering, and loss of life that took place in Cyprus during previous times of conflict.

Maria Hadjipavlou gives this insight in her paper at a conference in 2001:

Everywhere in Cyprus, today (27 years after the forced geographical division) the conflict and enemy images are still visible in the barbed wires, the military posts, the blue beret, and the blue and green posters which read 'Buffer UN Zone', 'Beware Mine Fields', 'No Entry', 'Occupied Zone', 'Dead Zone', 'No Photographs', 'Security Zone'. Flags of all kinds wave together or apart. The Greek flag, the flag of the 
Cyprus Republic, the red Turkish flag, the blue UN flag, and the 'Turkish Republic of Northern Cyprus' (TRNC) flag, sometimes fly next to each other (p. 25).

Most of those visual influences still remain intact as recently as April 2010. How do those negative visual cues impact the perception of the Greek Cypriots and Turkish Cypriots? Does the constant visual reminder of the past pain and suffering committed by the other alter the possibility for forgiveness, and moving forward to a solution for Cyprus?

As previously mentioned, the dilemma for some Greek Cypriots in general is that crossing into the north implies recognition of the northern side of the island. It was expressed to the researcher by some Greek Cypriots over coffee or at dinner that crossing into the north and making purchases, was one way to give recognition to the Turkish Republic of the north. Even now, some hide the fact that they cross into the north from their families; "just to keep peace" is what the researcher was told by one Greek Cypriot. Though all Cypriots are now allowed to cross, one has to wonder if that is really true for all. Even though they are now allowed to cross, family allegiance clearly appears to supersede that right for some. The researcher noted that along with the visual images of division is the language that encourages separation, and perpetuates the idea of victimization.

Bryant (2004) refers to commonly heard phrases, "In Greek Cypriot rhetoric, the northern part of Cyprus is referred to as 'occupied areas,' while the south constitutes the 'free zone"' (p. 5). Those phrases infer a frame of reference from which to view each side of Cyprus. How does freedom of movement feel when it takes you into the occupied 
area? How do the people who live in the occupied area feel about the legal right to now enter the free zone? Could saying, or hearing those phrases persuade one's perception to a certain viewpoint from which to filter all new information?

The researcher noted that some Turkish Cypriots in general believe that a legal and political division of Cyprus could be the solution. It is conceivable to some that the separate states named the Turkish Republic of Northern Cyprus, and the Republic of Cyprus could be the logical plan to live peacefully together on the island. That is one of the many ideas that have been discussed as a possible solution in Cyprus.

Professor Dr. Peter Permthaler (1998) analyzes the situation in Cyprus based on previous history and leadership. He advocates separation as a possible solution. "We have to accept that the reconstruction of the constitution of 1960 is impossible. Thus, the territorial separation and the establishment of a Turkish Cypriot Republic is the only realistic alternative to guarantee human rights and the right of self-determination to the Turkish population” Located in, Confederation: A lawyers brief. Retrieved from (http://www.cyprus-conflict.net/confederation). Many Turkish Cypriots suggested to the researcher that option of separation on several separate occasions while in Cyprus.

Some Turkish Cypriots gave the impression that living, as they are, on two separate sides works just fine. "Why change it, when it is working? Just leave it alone", was the comment heard many times. The researcher would like to note however that not all Turkish Cypriots and Greek Cypriots agreed with that philosophy. Though there is a separation still, and that does bother many of the Greek Cypriots and Turkish Cypriots, at least now they can cross freely if so desired. That ability to cross allows for freedom of 
movement for all Greek Cypriots and Turkish Cypriots on the island, though some choose not to cross for personal or political reasons.

Prior to the opening of the checkpoints many Greek Cypriots and Turkish Cypriots longed for the opportunity to see their old homes, or their favorite childhood places on the other side. Now that the checkpoints have been opened, a new set of issues has arisen. For some Greek Cypriots and Turkish Cypriots it is a positive experience to cross and experience the whole island, and for some it has only reactivated the memories of old traumas.

Each Greek Cypriot and Turkish Cypriot filters all new information through the lens of the past. What if those past memories include the forced removal from their home as a child, or of their father going missing, or the forced participation in the military that required them to see their neighbor as the enemy, who they must kill? How does the opening of the checkpoints look and feel to them? For many Greek Cypriots and Turkish Cypriots, crossing to the other side has brought back the ghosts of the past, the losses, and great sadness. For some, those years of longing to see their old villages, and imagining what once was is now over. For now they have visited their old villages, and what they see it is not as they remembered. For many it was almost "unbearable" according to a conversation with one Greek Cypriot.

\section{Referendum and the Annan Plan}

When asked about the referendum and the Annan Plan, both Turkish Cypriots and Greek Cypriots who were interviewed agreed that the information given to them by their respective leadership had a persuasive effect on them. Who was in leadership 
leading up to the referendum and a definition of "ethno-centric nationalism". Anastasiou (2007) describes whom the leadership was leading up the referendum:

In this process, the interlocutors that came to the historical forefront were Raulf Denktash, the life-long leader of the TCs and unilaterally selfdeclared president of the breakaway TRNC, and Tassos Papadopoulos, long-standing politician who, while leading a party representing merely $14 \%$ of the electorate, became president of the GC-controlled Republic of Cyprus through a coalition government (p. 191).

Although they are long standing rivals Anastasiou points out a commonality between both leaders, "...they both operated from a ethno-centric nationalist approach..."

Anastasiou $(2002,2007)$ defines ethno-centric nationalism:

Nationalism caries a view of 'the nation' that is absolute and sacred in value, mono-ethnic in nature, collectivist and narcissistic in mentality, conflictual in predisposition, and militant in its concept of defense and its means of freedom.... It conceptualizes society in terms of a single, homogeneous ethnic identity, thus rendering the existence of other ethnic groups in the body social a 'national anomaly' and, in times of conflict, a 'national blemish' that needs to be cleansed...(p. 582, 192).

From Anastasiou's definition of nationalism one can better understand that in a nationalists mind democracy occurs within ones own ethnic group never between different ethnic groups. Leading up to the referendum the Turkish Cypriot and Greek Cypriot leadership also relied on some of the old nationalistic rhetoric to prod the emotions of the people.

The approach that the Turkish Cypriots interviewed reported was to separate the Annan Plan into smaller more manageable sections, and have discussions each night on television about each separate section. This allowed for a step-by-step understanding of the plan. In addition, the Turkish Cypriots had time to discuss what they had learned the night before with co-workers and friends. Many of the Turkish Cypriots took this 
information very seriously, and used it as a place from which to start further discussions with each other about the pros and cons of the Annan Plan.

The Greek Cypriots interviewed conveyed that the general population of Greek Cypriots had a sense of confusion and misunderstanding about the plan. The Greek Cypriot population in general thought that the plan was terribly unfair toward them based on their understanding of the plan. The media encouraged the Greek Cypriots to vote against the Annan Plan. It was conveyed to the researcher that those Greek Cypriots who thought the Annan Plan could be a viable option were looked at as traitors. One Greek Cypriot stated, "Nationalism was unleashed, people were not thinking rationally." Nationalism, according to many has been one of the main contributors to the longstanding conflict in Cyprus.

Both the Turkish Cypriots and the Greek Cypriots have selected certain historical facts to embrace as the truth and have chosen to ignore the rest that do not fit into their nationalistic mindset. Those historical facts usually involve suffering at the hand of the other, and are frequently brought to light when the need arises, typically during a time of crisis. This selective memory is activated in times of crisis to rally the group together. When the individuals begin to think as the group, there is a thrust of power. The referendum created a stressful environment fertile for nationalism. As one Greek Cypriot interviewed stated, the media attacked the plan and the government parties manipulated the information. Also certain elements of the plan were emphasized by the leaders to create fear among the Greek Cypriots.

Sommer (2005) gives an assessment. "According to the politicians of the Greek 
Cypriot 'No' camp at the referendum, Turkey's troops in Cyprus constitutes a big threat to the Greek Cypriots. The underlying attitudes of Greek Cypriots show a strong nationalist prejudice". Again, historical influence has a negative impact. "Behind these attitudes lies a perception of history, where most Greek Cypriots see themselves as victims of an outside aggression and tend to forget inter-communal strife that was initiated and fuelled by Greek Cypriots at least from 1963 onwards" (p. 43,44).

Two of the main issues for the Greek Cypriots are that the Turkish military need to leave the island, and the return of Greek Cypriot land that was taken from them and given to the Turkish Cypriots. Many Greek Cypriots felt that what the Annan Plan had to offer was unfair and did not address those two issues. That was one thing that both the Greek Cypriots and the Turkish Cypriots interviewed agreed upon, they both felt that the plan was not fair. The difference observed was that even though they perceived the plan as not entirely fair, the Turkish Cypriots in general seemed to see it as a best option, or at least a good starting point with modifications in the future. On the other hand, the Greek Cypriots in general seemed to feel that if they held out, something better would be created.

It is worth noting that during the referendum that the Turkish Cypriots who had in the past been pro-separation become more pro-peace and voted yes for the Annan Plan even though it meant a united Cyprus. On the other side the Greek Cypriots shifted to a more nationalist viewpoint and were not willing to except joining with a different ethnic group even though it meant a possible positive step toward a united Cyprus.

So the result of the vote reflects the unique perceptions that Greek Cypriots and 
Turkish Cypriots acquired throughout the years. Would the Annan Plan have passed, if the information that the Greek Cypriot community received had been the same as the Turkish Cypriots? Was it the best decision for the Greek Cypriot leadership to influence the people to vote no on the Annan Plan? That raises the question; how does perception affect the decision-making process of each individual?

\section{EU Membership}

The issue of not having a voice in the EU as a Turkish Cypriot was an important issue that many stated as very problematic during the interviews. Some Turkish Cypriots expressed that by Cyprus joining the EU as a divided country it has created a feeling of superiority among the Greek Cypriots, as they are the political voice for the entire island. In the north, where the majority of Turkish Cypriots live and struggle as the unrecognized side of the island they feel that the same political voice is denied to them. They feel that the lack of voice serves to enhance their feelings of inferiority and only increases the feelings of division even more. Some of the Turkish Cypriots interviewed also commented that the EU has made promises to them about increased trade opportunities but so far there has not been a significant change in the economic situation in northern Cyprus. Most of the Turkish Cypriots interviewed saw EU membership being more positive for the Greek Cypriots because of the benefits the Greek Cypriots would receive, but saw very limited benefits for themselves.

On the other hand during the interviews the Greek Cypriots saw both economic benefits to themselves as well as an increased sense of security gained from joining the EU. The researcher was told this sense of security comes from being part of a larger 
group so now they do not feel as threaten by Turkeys progression toward entering the EU. Some of the Greek Cypriots interviewed expressed their belief that joining the EU could possibly be the solution to the Cyprus problem. One Greek Cypriot interviewed suggested even without a "solution" the gradual steps to conform to the EU standards would gradually solve the problem. That same person also said, "This is a Greek island". With that perception of Cyprus as a Greek island, what affect does that have on the possibility of a solution that will benefit both Greek Cypriot and Turkish Cypriot? The position taken by some Greek Cypriots that Cyprus is a 'Greek island' is reminiscent of the past nationalistic desires toward the Hellenism of Cyprus.

Based on interviews and many conversations with Greek Cypriots and Turkish Cypriots, both clearly saw EU membership as having certain benefits. In addition, most Turkish Cypriots and Greek Cypriots saw the benefits would be much greater for the Greek Cypriots. One of the frustrations expressed by Turkish Cypriots interviewed and in general, was the promise of more trade. Both from the northern side of Cyprus across to the south, and to other countries outside of Cyprus, this has not happened yet. The Turkish Cypriots interviewed and most in general still feel a sense of profound isolation from the rest of the world.

Many of the Turkish Cypriots and Greek Cypriots in general saw joining the EU as a step to the solution, and others are still waiting. Some of the basic improvements such as more educational opportunities abroad and easier travel with a EU passport have only left many wanting more. Noted, was the perception of the benefits and drawbacks of EU membership for Cyprus varied greatly depending on whether that person lived in the north, or the south. 


\section{Chapter Seven}

\section{Conclusion}

The goal of this thesis was to offer a limited amount of historical information in regard to the country of Cyprus and to convey how that history including two significant conflicts has altered the Turkish Cypriot and Greek Cypriot perception about three specific recent events. Those events are the; opening of the checkpoints; the referendum and the Annan Plan; EU membership. This thesis by no means intends to present a thorough historical background for Cyprus, nor does it have the solution for the Cyprus problem.

What is hoped for is the reader to gain a snapshot of historical background and be provoked to ponder how does perception affect the new information given to each individual. In specific, how does the past conflict habituated history of the Greek Cypriots and Turkish Cypriots affect their perception in regard to the three recent events asked about during the interview? This thesis has attempted to show the perceptions of many Greek Cypriots and Turkish Cypriots in Cyprus.

After presenting a limited historical background of Cyprus from the perspective of many different scholarly academics, the paper hopes to give some insight to the reader as too just how different the perspectives of the same event can be. The research suggests, that the past events that each Turkish Cypriot and Greek Cypriot has lived through or been exposed to in Cyprus, has altered what, or how, they receive new information. This thesis has attempted to show how each Turkish Cypriot and Greek Cypriot specifically, but also how each person in general filters all new incoming information through their 
past knowledge. That if in fact, that past knowledge includes hostile conflicts, loss of life, imprisonment and severe traumatic experiences, there will be a negative effect on how those individuals perceive new information in the future?

An interesting observation was the lack of consensus among the Greek Cypriots and Turkish Cypriots interviewed, in regard to their responses to the questions. The lack of unanimous agreement in itself is somewhat of an anomaly in Cyprus. As was put forth by the research, that is one of the more common traits among the Greek Cypriots and Turkish Cypriots in general. Nationalism has encouraged those who are the 'same' to be in agreement and remain united. The lack of agreement and the varying responses to the questions leaves one to wonder.

Is it conceivable that the lack of agreement in this specific group of people interviewed is the consequence of conflict resolution training? Is there a convincing argument that a less rigid nationalist view has been brought about by conflict resolution training and participating in peace enhancing programs? The focus of this paper was to find how the past had impacted each Greek Cypriot and Turkish Cypriots perceptions, not the positive benefits of conflict resolution training. Though it does make one wonder if conflict resolution training could have a positive effect on the perception of those people who live in countries that have been negatively impacted by nationalism and conflict? As was illustrated through the research everyone is influenced by their past and what they learn along the way. This theory also applies to the person doing the research.

As the researcher lived and interacted with both Greek Cypriots and Turkish Cypriots it became apparent how important perception can be. As an American 
researcher living in Cyprus all new information received from the Greek Cypriots and Turkish Cypriots was filtered through the lens of being an American. The researcher made every effort to remain unbiased and stay neutral during the research process. The researcher noted that with the daily interactions and the multiple trips to Cyprus there was a more clear understanding of the Greek Cypriot and Turkish Cypriot's perspective. It became easier to see through the eyes of the Cypriots, and to understand their feelings about those three specific events.

"How does the past affect the future"? With that question in mind the researcher gives consideration to the person who has been trained in conflict resolution techniques and is skilled in negotiation and mediation. The trained negotiator may have the knowledge and skills to help the people in that community post conflict, but what do those people really hear? The researcher poses the question: What is the most productive and healing operandi to reach people post conflict, given that traumatic experience will be what all new information is going to be filtered through?

This thesis does not have the answers to those questions. It does however hope to challenge and encourage others to give further consideration to how the past may alter how each individual filters all new information given to them and to consider the positive effects of conflict resolution training for all. 


\section{References}

Alter, P (1994). Nationalism. New York, New York: Oxford University Press. Anastasiou, H (2002). Communication Across Conflict Lines: The Case of Ethnically Divided Cyprus. Journal of Peace Research, 39 (5) 581-596.

Anastasiou, H (2008)a. The Broken Olive Branch: Narionalism, Ethnic Conflict and the Quest for Peace in Cyprus. Syracuse, NY: Syracruse University Press.

Anastasiou, H (2008)b. The Broken Olive Branch: Narionalism, Ethnic Conflict and the Quest for Peace in Cyprus. Syracuse, NY: Syracruse University Press.

Anastasiou, H (2007). Nationalism as a Deterrent to Peace and Interethnic Democracy: The Failure of Nationalist Leadership From the Hague Talks to the Cyprus Referendum. International Studies Perspectives 8, 190-205.

Anastasiou, H (2007). The Communication Imperative in an Era of Globalization: Beyound Conflict-Conditioned Communication. Global Media Journal:

Mediterranean Edition 2 (1), Spring 2007.

Annan, K (2004). Remarks at the closing of the Cyprus Talks: accessed from http://www.hri.org on July, 2007.

Attalides, M (2003). Cyprus: Nationalism and International Politics. Mannheim:

Bibliopolis

Augsburger, D (1992). Conflict Nediation Across Cultures: Pathways \& Patterns. Louisville, KY: Westminster John Knox Press.

Barash, D (1994). Beloved Enemies: Our Need For Opponents. Amherst, New York: Prometheus Books.

BBC News. Timeline: Cyprus. Accessed from http://newsvote.bbc.co.uk on June, 2006.

Bohm, D (1996). On Dialogue. New York, New York: Routledge.

Broome, B (2004). Reaching Across the Dividing Line: Building a Collective

Vision for Peace in Cyprus. Journal of Peace Research, 41 (2) 191-209.

Broome, B (2005). Building Bridges Across the Green Line: A Guide to Intercultural Communication in Cyprus. Nicosia, Cyprus: Action Global 
Communication.

Bryant, R (2004). An Ironic Result in Cyprus. Middle East Report Online. Accessed from http://www.cyprus-conflict.net on November, 2007.

Constantinou, C, Papadakis, Y (2001). Across the Green Line: Problems of

"Recognition”. Academic Journal, Global Society: Accessed from

http://www.cyprus-conflict.net on November, 2007.

Creswell, J (2003). Research Design: Qualitative, Quantitative, and Mixed

Methods Approaches. Thousand Oaks, CA: Sage Publications.

Ergun, D, Cakici, M, Cakici, E (2008). Comparing Psychological Responses of

Internally Displaced and Non-Displaced Turkish Cypriots. Torture, Volume, 18 (1) 20-

28.

Faustmann, H (2004). The Reunification Process in Germany: Similarities and

Differences with Regard to Cyprus. Paper presented at a Symposium in Nicosia,

Cyprus.

Galtung, J (1964). An Editorial, Journal of Peace Research, 1 (1), 1-4.

Hadjipavlou, M (2007). Multiple Stories; the 'Crossings' as part of Citizens'

Reconciliation Efforts in Cyprus? Innovation, 20 (1), 53-73.

Hadjipavlou-Trigeorgis, M. \& Trigeorgis, L (1993). Cyprus: An Evolutionary

Approach to Conflict Resolution. Journal of Conflict Resolution, 37 (37), 340-360.

Hadjipavlou-Trigeorgis, M (2001). Report: Cypriot Women's Contribution to

Conflict Resolution-Successes and Limitations. Paper presented at 24 Council of

Europe International Seminar in Strasbourg, September 20-21.

Hannay, D (2005). Cyprus: The Search for a Solution. New York, New York: I.B.

Tauris.

Ignatieff, M (1993). Blood and Belonging: Journeys Into the New Nationalism.

London: BBC Books

Lederach, J (1996). Preparing for Peace: Conflict Transformation Across Cultures.

Syracuse, New York: Syracuse University Press.

Loizos, P (1988). Intercommunal Killing in Cyprus. Man, New Series, 23 (4) 639653. 
Oztoprak, C (2000). The Experience of Bi-Communal Contacts Through the Eyes of a Turkish Cypriot: Facts and Fictions. Paper presented at an international conference in California: Accessed from, http://www.cyprus-conflict.net on November, 2007. Papadakis, Y (2005). Echoes From the Dead Zone; Across the Cyprus Divide. New York, New York: I.B. Tauris.

Pernthaler, P (1998). A Federal or Confederal Solution to the Cyprus Problem? Based on a speech given at the International Association of Centers for Federal Studies in Jerusalem; Accessed from http://www.cyprus-conflict.net on August, 2006.

Saner, R, Yiu, L (2001). External Stakeholder Impact on Third-Party Interventions in Resolving Malignant Conflicts: The Case of a Failed Third-Party Intervention in Cyprus. International Negotiation 6, 387-416.

Sommer, J (2005). Security in Cyprus; Threat Perceptions, Possible Compromises and the Role of the EU. Paper 44: The Bonn International Center for Conversion. U.S. Department of State. Bureau of European and Eurasian Affairs: Accessed from, http://www.state.gov, on August, 2007.

Volkan, V (1997). Blood Lines: From Ethnic Pride to Ethnic Terrorism. Boulder, Colorado: Westview Press.

Volkan, V (2004). Blind Trust: Large Groups and Their Leaders in Times of Crisis and Terror. Charlottesville, VA: Pitchstone Publishing.

Wolleh, O (2001). Cyprus: Citizen's Rapprochement by the Bi-Communal Trainer Group.Berghof Report, Nr 8: Accessed from, http://www.berghof.center.de on November, 2006.

Yilmaz, M (2005). The Cyprus Conflict and the Question of Identity. Journal of Turkish Weekly: Accessed from, http://www.turkishweekly.net on November, 2007. 


\section{Appendix: Survey Instrument Interview Questions}

When considering your answer to the following questions we ask that you give us your own personal perspective on each of the questions.

\section{Opening of the Check Points}

1. How do you assess the climate that was created following the opening of the checkpoints?

2. Why did large numbers of people cross when the checkpoints first opened, and now not as many?

3. Has the opening of the checkpoints created new obstacles and/or new opportunities? Explain.

4. Has the opening of the checkpoints been peace enhancing or conflict enhancing? How?

5. Given the current conditions, do you think that the mixing of the two communities will contribute to the future reunification of the island or deter it?

\section{Referendum \& the Annan Plan}

1. What was your view of the Annan Plan: an opportunity for peace or an injustice against your community?

2. How do you assess your community's understanding of the Annan Plan?

3. How do you assess the role that the political leadership of your community played in the outcome of the referendum?

4. If the Annan Plan or one similar to it would be reintroduced today, do you think it would have the same support in your community as it did in 2004 ?

5. How do you think the outcome of the 2004 referendum will impact future attempts for a solution and another referendum? 


\section{EU Membership}

1. Has joining of the EU been positive and/or negative for GCs? How? Explain.

2. Has joining of the EU been positive and/or negative for TCs? How? Explain.

3. Has EU membership improved or undermined TC-GC relations? Explain.

4. Has EU membership improved or undermined Greek-Turkish relations?

5. Has EU membership improved or undermined relations between the Republic of Cyprus and Turkey?

6. Do you see EU membership as contributing or obstructing a future solution of the Cyprus problem? 